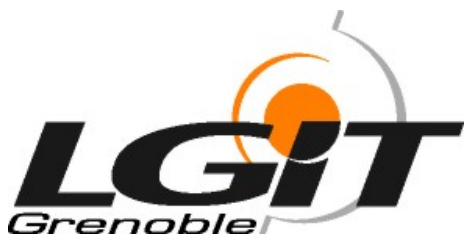

\title{
Ambient Vibration and Earthquake Strong-Motion Data Sets for Selected USGS Extensively Instrumented Buildings
}

By François Dunand ${ }^{1}$, Janise E. Rodgers ${ }^{2}$, Arnold V. Acosta ${ }^{2}$, Marion Salsman ${ }^{2}$, Pierre-Yves Bard ${ }^{1}$, and Mehmet Çelebi ${ }^{2}$

Any use of trade, firm, or product names is for descriptive purposes only and does not imply endorsement by the U.S. Government

\section{Open-File Report 2004-1375}

\section{U.S. Department of the Interior} U.S. Geological Survey

\footnotetext{
${ }^{1}$ Laboratorie de Geophysique Interne et Tectonophysique (LGIT), Grenoble, France

${ }^{2}$ U.S. Geological Survey, Menlo Park, California
} 


\section{Table of Contents}

Table of Contents.

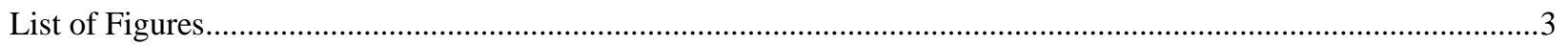

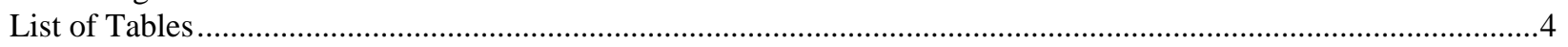

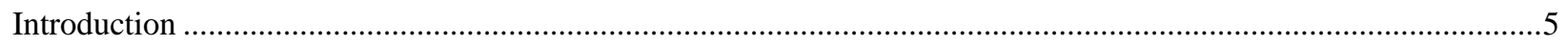

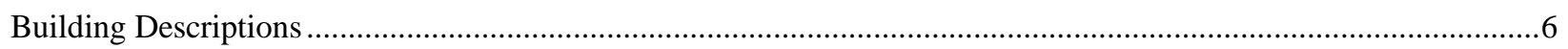

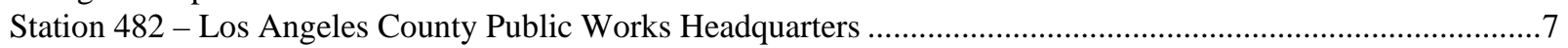

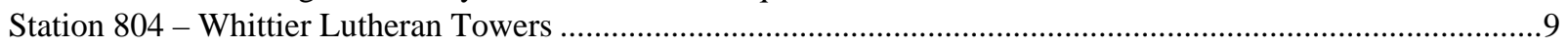

Station 1103 - Former Great Western Savings Building .......................................................................................10

Station 1225 - San Francisco VA Hospital, Building 2 .....................................................................................12

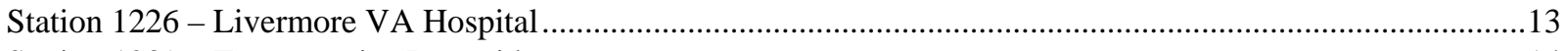

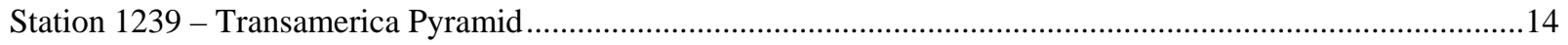

Station 1662 - Pacific Park Plaza ........................................................................................................

Station 5106 - Long Beach VA Hospital .........................................................................................................18

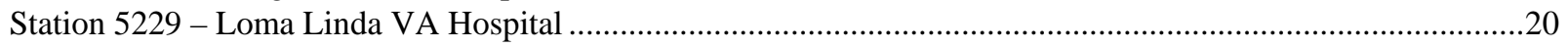

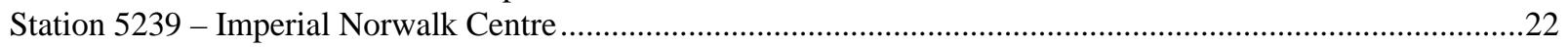

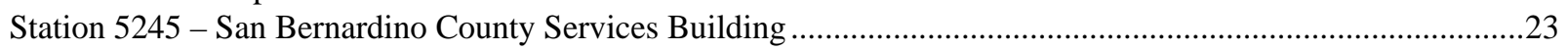

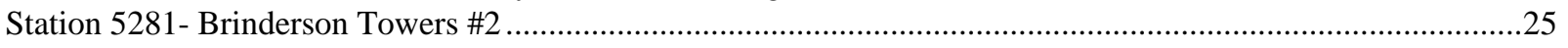

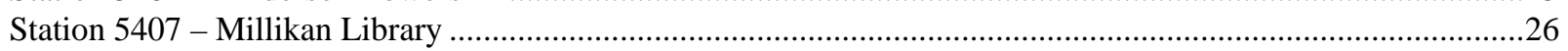

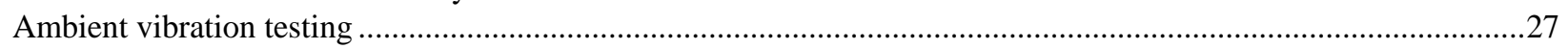

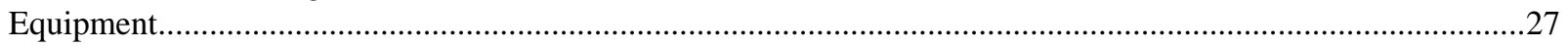

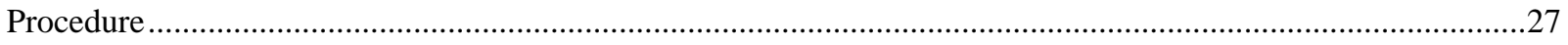

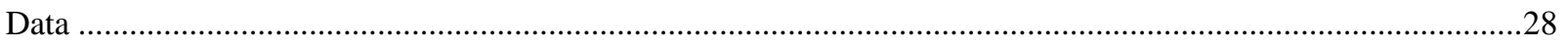

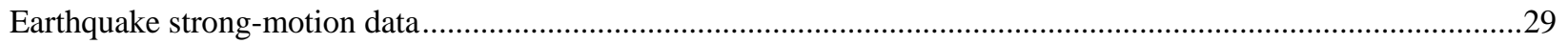

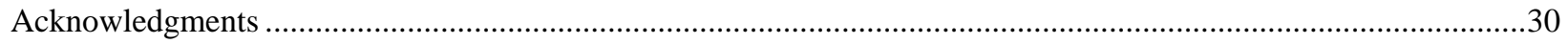

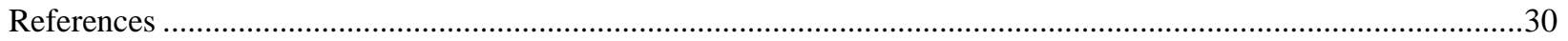




\section{List of Figures}

Figure 1. 900 S. Fremont St. exterior (left) and strong-motion and ambient testing instrument setup (right) (photos by Janise Rodgers).

Figure 2. Instrumentation schemes and ambient vibration measurement locations for 900 S. Fremont St.: code instrumentation 1971-1989 (left) and extensive instrumentation 1989-present (right). Instrumented floors are blue, accelerometer locations are marked by red arrows, and ambient vibration measurement locations are marked by green cylinders.

Figure 3. Exterior view of 7215 Bright. Ave. (photo by Janise Rodgers) ……………...........................................9

Figure 4. Instrumentation scheme and ambient vibration measurement locations for 7215 Bright Ave.......................9

Figure 5. Exterior view of 2150 Shattuck Ave. (photo by Arnold Acosta) ..............................................................10

Figure 6. Instrumentation scheme and ambient vibration measurement locations for 2150 Shattuck Ave. (channels 10 and 11 not currently in service)

Figure 7. Exterior view of 4150 Clement St., Building 2 (photo by François Dunand) ............................................12

Figure 8. Instrumentation scheme and ambient vibration measurement locations for 4150 Clement St.....................12

Figure 9. Exterior view of 4951 Arroyo Rd. (photo by François Dunand) ...............................................................13

Figure 10. Instrumentation scheme and ambient vibration measurement locations for 4951 Arroyo Rd.....................13

Figure 11. Exterior view of 600 Montgomery St. (photo by Dan Radulescu) ..........................................................14

Figure 12. Instrumentation scheme for 600 Montgomery St. Lower floor channels are: 14, 15, 18, 19, 20, 21 atop basemat, 13, 15, 17 at ground level, and 4, 8, 12 at $5^{\text {th }}$ floor. ............................................................................15

Figure 13. Exterior view of 6363 Christie Ave. with adjacent reinforced concrete parking garage in foreground (photo by Kent Fogleman) .............................................................................................................................16

Figure 14. Instrumentation scheme and ambient vibration measurement locations for 6363 Christie Ave. Ambient velocity measurements taken on $30^{\text {th }}$ floor while permanent instruments are located on roof. …......................17

Figure 15. Exterior view of 5901 E. $7^{\text {th }}$ St. (photo by Arnold Acosta) .....................................................................18

Figure 16. Instrumentation scheme for $5901 \mathrm{E}$. $7^{\text {th }}$ St., showing configurations before (left) and after (right) seismic

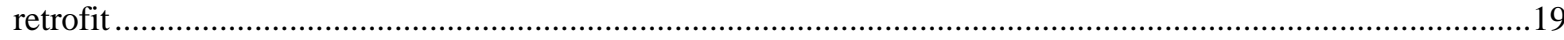

Figure 17. Wide-angle (left) and close-up (right) exterior views of 11201 Benton St. (photos by Janise Rodgers and François Dunand) .20

Figure 18. Instrumentation scheme and ambient vibration measurement locations for 11201 Benton St. Accelerometer channel numbers are 1-3, 5, 8 on the $1^{\text {st }}$ floor, and 4, 6, 7, 9 on the roof. A new digital tri-axial package is in the basement. Ambient vibration measurements were taken at the basement, $1^{\text {st }}$ floor and roof...21

Figure 19. Instrumentation scheme and ambient vibration measurement locations for 12440 Imperial Hwy. Accelerometer channel numbers: 10-12 downhole; 5, 7-9 at basement; 4, 16, 20, 24 on $1^{\text {st }}$ floor; 3, 15, 19, 23 on $2^{\text {nd }}$ floor; 2, 6, 14, 18, 22 on $6^{\text {th }}$ floor, $1,13,17,18,21$ at roof. .

Figure 20. Front (left) and rear (right) exterior views of 345 N. Arrowhead Ave. (photos by Janise Rodgers and François Dunand) .. .23

Figure 21. Instrumentation scheme and ambient vibration measurement locations for $345 \mathrm{~N}$. Arrowhead Ave. Ambient velocity measurements were taken at two locations on the roof and at one in the maintenance basement.

Figure 22. Exterior view of 19900 MacArthur Blvd., Tower 2 (photo by Janise Rodgers)........................................25

Figure 23. Instrumentation scheme and ambient vibration measurement locations for 19900 MacArthur Blvd. .......25

Figure 24. Exterior view of Millikan Library (photo by François Dunand) .............................................................26

Figure 25. Instrumentation scheme and ambient vibration measurement locations for Millikan Library ....................26

Figure 26. The CityShark ${ }^{*}$ recorder and the Lennartz LE-3D ${ }^{*}$ velocimeter ..............................................................27 


\section{List of Tables}

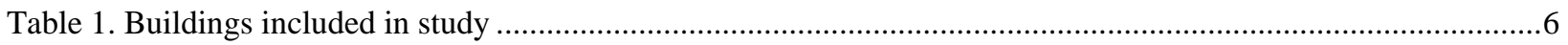

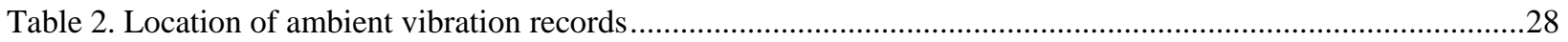

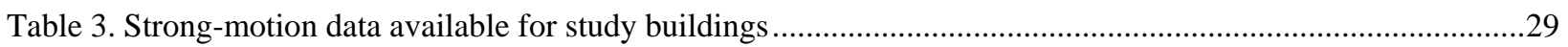

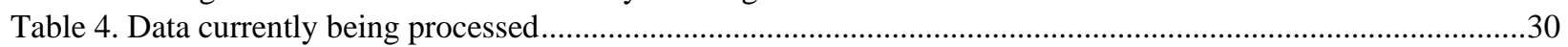




\title{
Ambient Vibration and Earthquake Strong Motion-Data Sets for Selected USGS Extensively Instrumented Buildings
}

\author{
By François Dunand ${ }^{1}$, Janise E. Rodgers ${ }^{2}$, Arnold V. Acosta ${ }^{2}$, Marion Salsman ${ }^{2}$, Pierre-Yves Bard ${ }^{1}$, and \\ Mehmet Çelebi ${ }^{2}$ \\ ${ }^{1}$ Laboratorie de Geophysique Interne et Tectonophysique (LGIT), Grenoble, France \\ ${ }^{2}$ U.S. Geological Survey, Menlo Park, California, USA
}

\section{Introduction}

The objective of this report is to present background information for a study comparing the dynamic characteristics of thirteen buildings obtained using strong-motion and ambient vibration records. Ambient vibration testing is an attractive method of measuring the dynamic characteristics of real buildings, since it does not disrupt building occupants and the necessary equipment is small, light, and very portable. However, because of the low amplitude range of the ambient vibration $\left(10^{-5} \mathrm{~g}\right)$, dynamic characteristics obtained from ambient vibration should be different from those obtained from strong-motion (>0.1 g) records due to non-linear effects (Çelebi 1993, Çelebi 1998).

The strong motion records were provided by the U.S. Geological Survey (USGS) National Strong-Motion Program (NSMP). At least one strong-motion record is available and has been processed for each building, and as many as sixteen seismic records are available for some buildings. Ambient vibration records were collected using velocimeters (velocity transducers). In order to test the efficiency of the ambient vibration for defining the dynamic parameters of structure, a set of three permanently instrumented buildings has been monitored using ambient vibration.

This report describes (1) the 13 buildings with their permanent instrumentation and locations where ambient data was recorded, (2) the ambient vibration testing, and (3) a description of the strong-motion data sets available for each building. This report contains background information only; no results are presented. 


\section{Building Descriptions}

The buildings selected for this study meet three criteria: (1) they are located in either the greater Los Angeles or San Francisco Bay areas; (2) they are extensively instrumented by the USGS; and (3) they have been strongly shaken by earthquakes with peak ground accelerations in excess of $10 \%$ of the acceleration of gravity. Study buildings are listed in Table 1.

Table 1. Buildings included in study

\begin{tabular}{|c|l|l|l|l|}
\hline $\begin{array}{c}\text { NSMP } \\
\text { Station }\end{array}$ & Building Name & City & Stories & Structural System \\
\hline 482 & LA County Public Works Headquarters & Alhambra & 13 & Steel moment frame \\
\hline 804 & Whittier Lutheran Towers & Whittier & 10 & Reinforced concrete moment frame \\
\hline 1103 & Former Great Western Savings & Berkeley & 13 & Proprietary lift-slab \\
\hline 1225 & San Francisco VA Hospital & San Francisco & 6 & Reinforced concrete shear wall \\
\hline 1226 & Livermore VA Hospital & Livermore & 6 & Reinforced concrete shear wall \\
\hline 1239 & Transamerica Pyramid & San Francisco & 49 & Steel moment frame \\
\hline 1662 & Pacific Park Plaza & Emeryville & 30 & Reinforced concrete moment frame \\
\hline 5106 & Long Beach VA Hospital & Long Beach & 11 & Base isolation retrofit w/shear walls \\
\hline 5229 & Loma Linda VA Hospital & Loma Linda & 4 & Reinforced concrete shear wall \\
\hline 5239 & Imperial Norwalk Centre & Norwalk & 7 & Steel moment frame \\
\hline 5245 & $\begin{array}{l}\text { San Bernardino County Services } \\
\text { Building }\end{array}$ & $\begin{array}{l}\text { San } \\
\text { Bernardino }\end{array}$ & & $\begin{array}{l}\text { Steel moment frame/braced frame } \\
\text { dual system }\end{array}$ \\
\hline 5281 & Brinderson Towers \#2 & Irvine & 13 & Steel moment frame \\
\hline 5407 & Millikan Library & Pasadena & 9 & Reinforced concrete shear wall \\
\hline
\end{tabular}

A brief description of building characteristics, photographs, and a schematic showing the locations of permanent instrumentation are provided for each building. Instrument placements for ambient vibration tests made using velocimeters (if performed) are shown relative to the permanent instrumentation. Floor levels where either permanent instruments are deployed or ambient vibration tests were performed are shown in blue on the schematics. Permanent accelerometer locations and directions are indicated by red arrows, and locations where ambient vibration measurements were taken are shown by green cylinders. 


\section{Station 482 - Los Angeles County Public Works Headquarters}

\section{South Fremont Street, Alhambra}

The thirteen-story Los Angeles County Public Works Headquarters, shown in Figure 1, was constructed in 1970. The structural system consists of large reinforced concrete piers and shear walls up to the second floor, with a steel moment frame with pre-Northridge connections above the second floor. Instrumentation configurations for the building are shown in Figure 2. The building was initially instrumented in 1971 with code-mandated tri-axial Kinemetrics SMA- ${ }^{*}$ analog accelerographs at the basement, $6^{\text {th }}$ floor, and $12^{\text {th }}$ floor. The instrumentation system was changed in 1989 to a structural array with three independent horizontal accelerometers at the $2^{\text {nd }}$, $6^{\text {th }}$, and $12^{\text {th }}$ floors, and a tri-axial accelerometer in the basement. Both torsional and translational accelerations can be measured at the $2^{\text {nd }}, 6^{\text {th }}$, and $12^{\text {th }}$ floors. An extensive set of strong-motion data is available and contains records from 1971 to present.
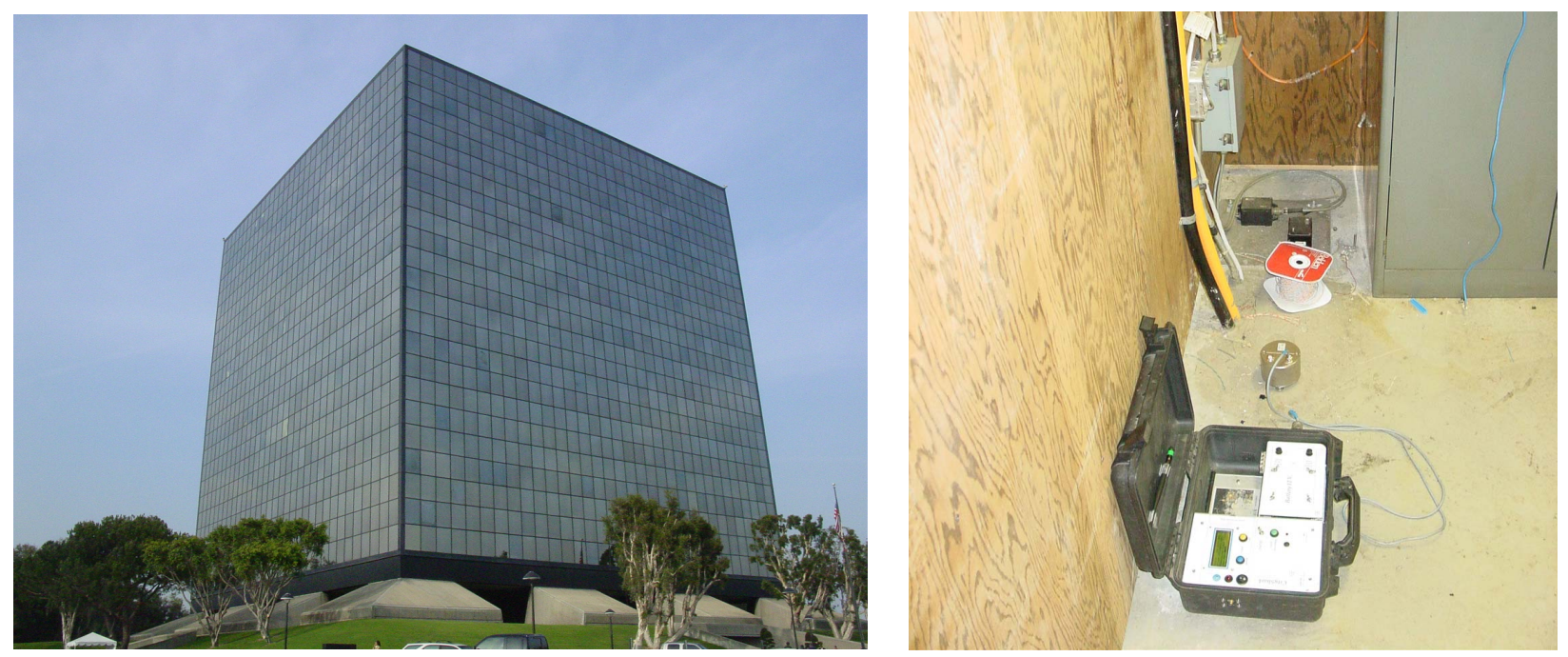

Figure 1. 900 S. Fremont St. exterior (left) and strong-motion and ambient testing instrument setup (right) (photos by Janise Rodgers)

\footnotetext{
${ }^{1 *}$ Use of trade, firm, or product names does not imply endorsement by the U.S. Government or the authors.
} 


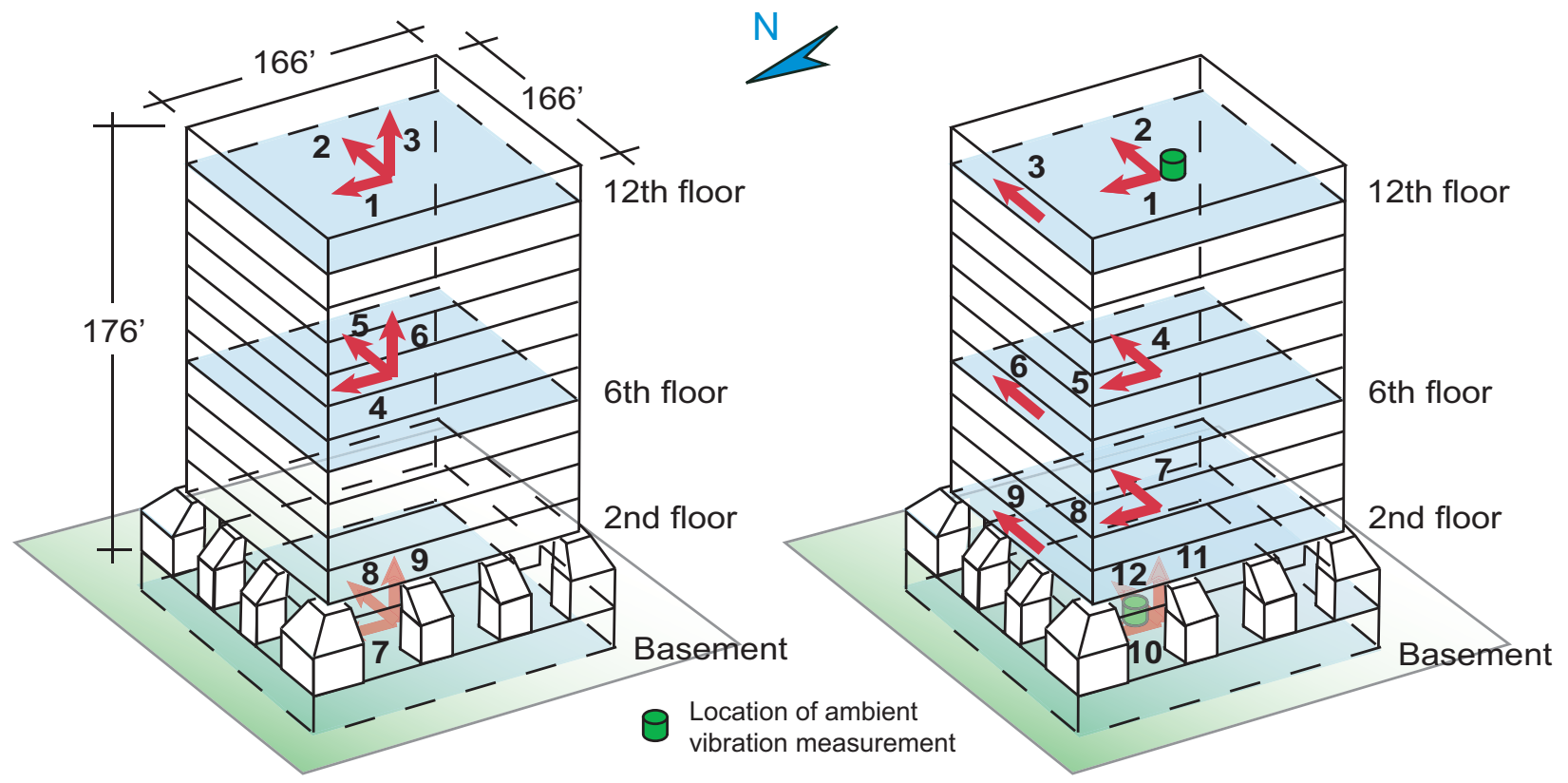

Figure 2. Instrumentation schemes and ambient vibration measurement locations for $900 \mathrm{~S}$. Fremont St.: code instrumentation 1971-1989 (left) and extensive instrumentation 1989-present (right). Instrumented floors are blue, accelerometer locations are marked by red arrows, and ambient vibration measurement locations are marked by green cylinders. 


\section{Station 804 - Whittier Lutheran Towers}

\section{Bright Avenue, Whittier}

The ten-story Whittier Lutheran Towers building, shown in Figure 3, was designed in 1973. The structural system consists of a ductile reinforced concrete moment frame with shear walls. The building's instrumentation, shown in Figure 4, consists of three tri-axial Kinemetrics SMA- $1^{*}$ analog accelerographs at the basement, $5^{\text {th }}$, and $10^{\text {th }}$ floors. A number of earthquakes, most notably the nearby 1987 Whittier Narrows quake and several large aftershocks, have been recorded by the instrumentation system.

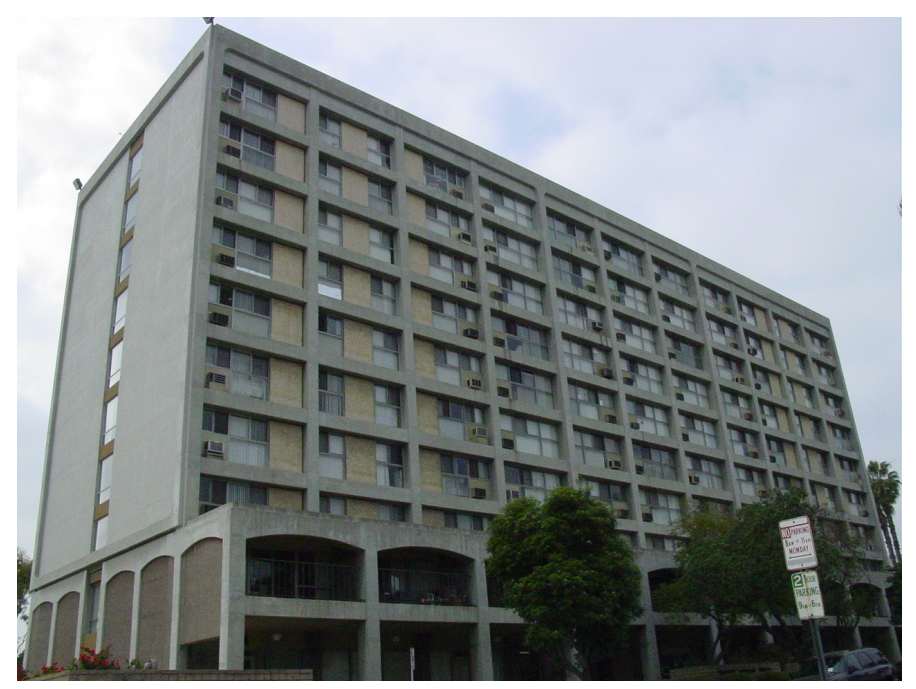

Figure 3. Exterior view of 7215 Bright. Ave. (photo by Janise Rodgers)

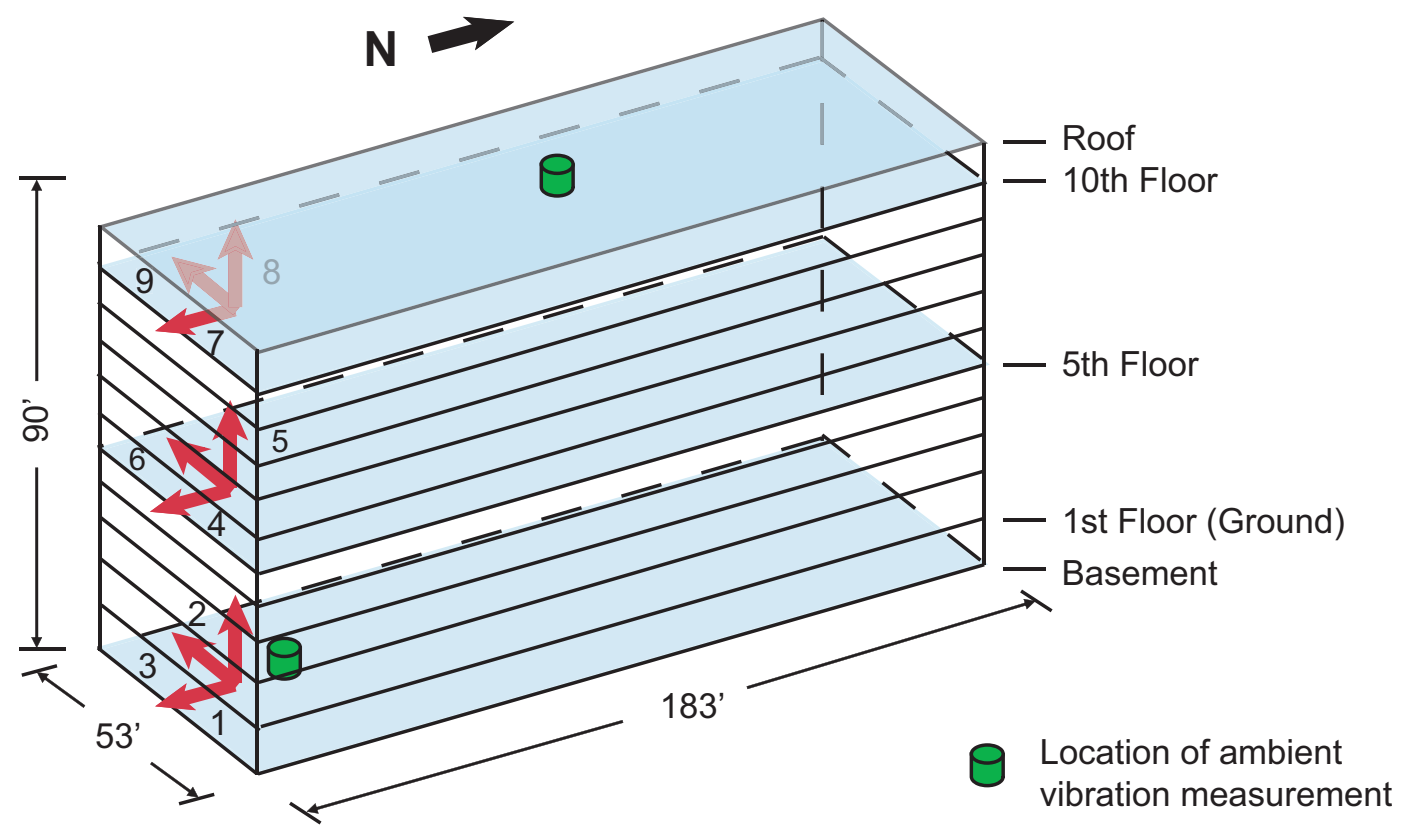

Figure 4. Instrumentation scheme and ambient vibration measurement locations for 7215 Bright Ave.

${ }^{*}$ Use of trade, firm, or product names does not imply endorsement by the U.S. Government or the authors. 


\section{Station 1103 - Former Great Western Savings Building}

\section{Shattuck Avenue, Berkeley}

The former Great Western Savings building, now adorned with a large "Powerbar" sign and accordingly dubbed the Powerbar building, was constructed in 1969. The fourteen-story building, shown in Figure 5, was constructed using an proprietary lift-slab structural system, with floors poured at the base of two concrete towers and then jacked into place. Due to the building's proximity to the Hayward Fault $(1.5 \mathrm{~km})$, it underwent a limited-scope, voluntary retrofit in 2000 described in Mar et al. (2000) following a vulnerability assessment. The building's current instrumentation scheme and ambient vibration measurement locations are shown in Figure 6. The instrumentation configuration differs slightly from that in place at the time of the 1989 Loma Prieta earthquake. Channels 10 and 11 were removed from service during a recent asbestos abatement program and have yet to be reinstalled.

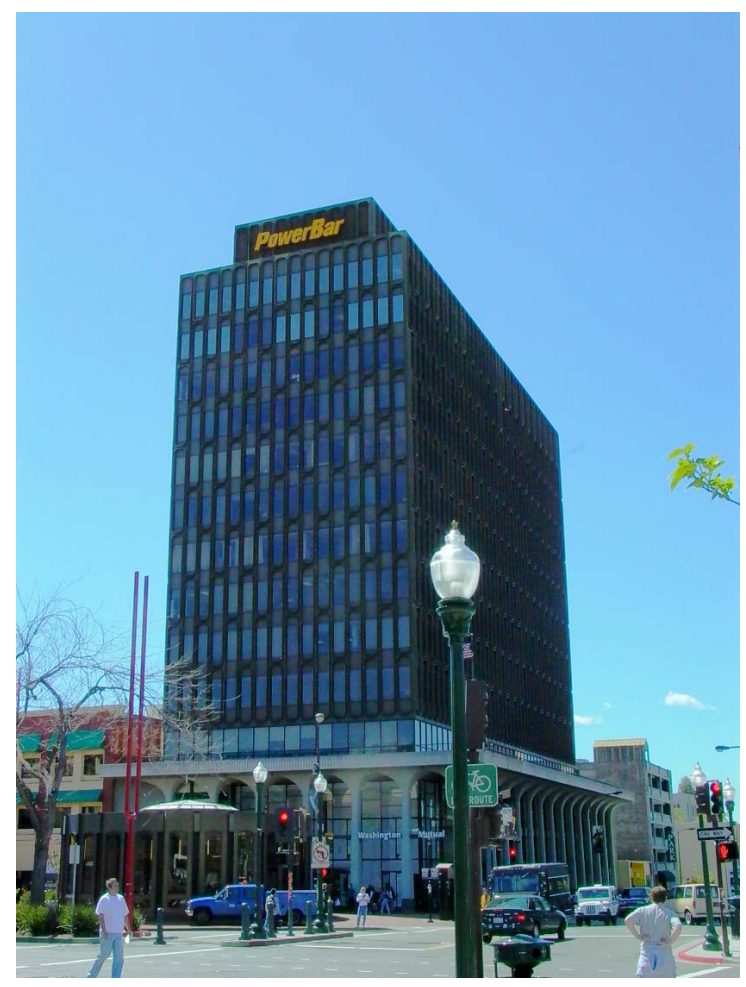

Figure 5. Exterior view of 2150 Shattuck Ave. (photo by Arnold Acosta) 


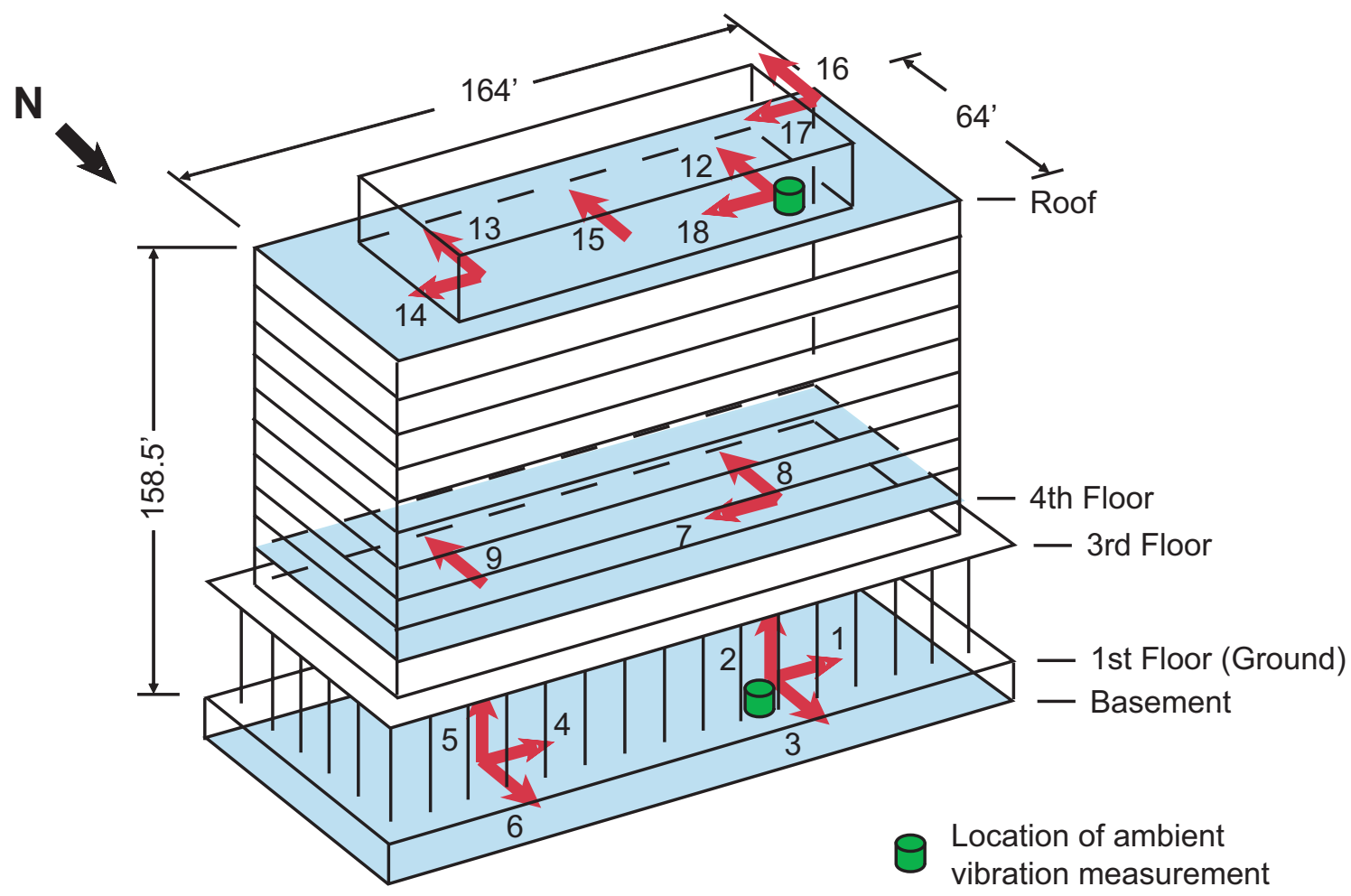

Figure 6. Instrumentation scheme and ambient vibration measurement locations for 2150 Shattuck Ave. (channels 10 and 11 not currently in service) 


\section{Station 1225 - San Francisco VA Hospital, Building 2}

\section{Clement Street, San Francisco}

Main Building Two of the Veterans Administration (VA) Hospital in San Francisco was constructed in the early 1930s. This seven-story C-shaped structure, shown in Figure 7, now forms the 'backbone' of the hospital's nine irregular, interconnected buildings, which are laid out roughly in a delta-wing shape. The lateral force-resisting system consists of nonductile reinforced concrete frames and walls. A remodel and seismic upgrade were performed in 1988-89 before the M6.9 1989 Loma Prieta earthquake. The instrumentation and ambient vibration measurement locations are shown in Figure 8. Permanent instrumentation at the time of the Loma Prieta earthquake consisted of two tri-axial analog accelerographs, which have recently been replaced by tri-axial digital instruments.

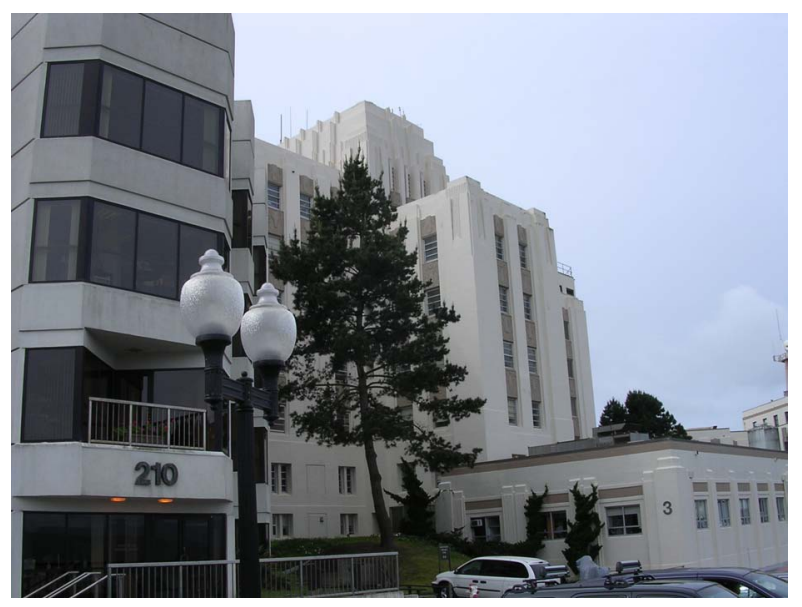

Figure 7. Exterior view of 4150 Clement St., Building 2 (photo by François Dunand)

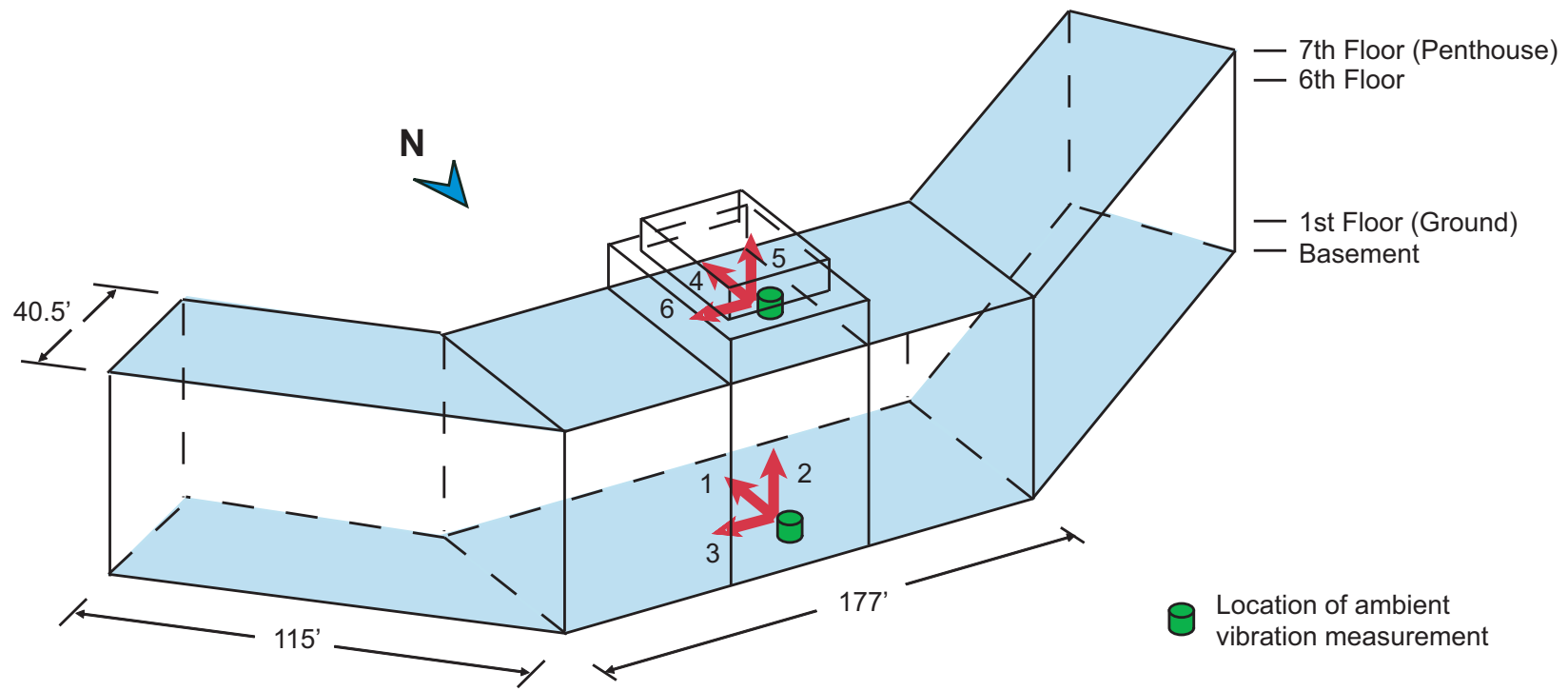

Figure 8. Instrumentation scheme and ambient vibration measurement locations for 4150 Clement St. 


\section{Station 1226 - Livermore VA Hospital}

\section{Arroyo Road, Livermore}

The seven-story Livermore VA Hospital, shown in Figure 9, was constructed between 1947 and 1955. The building is T-shaped and has a lateral force-resisting system consisting of reinforced concrete walls and framing. The building has had some seismic strengthening, also with reinforced concrete, but the extent is presently unknown. The instrumentation and ambient vibration measurement locations are shown in Figure 10. These analog instruments recorded the 1989 Loma Prieta earthquake and several smaller local events.

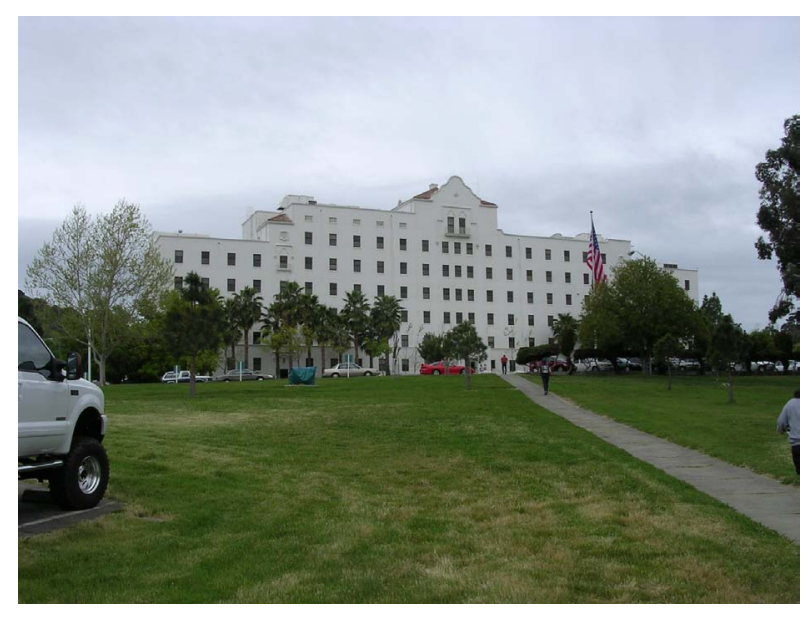

Figure 9. Exterior view of 4951 Arroyo Rd. (photo by François Dunand)

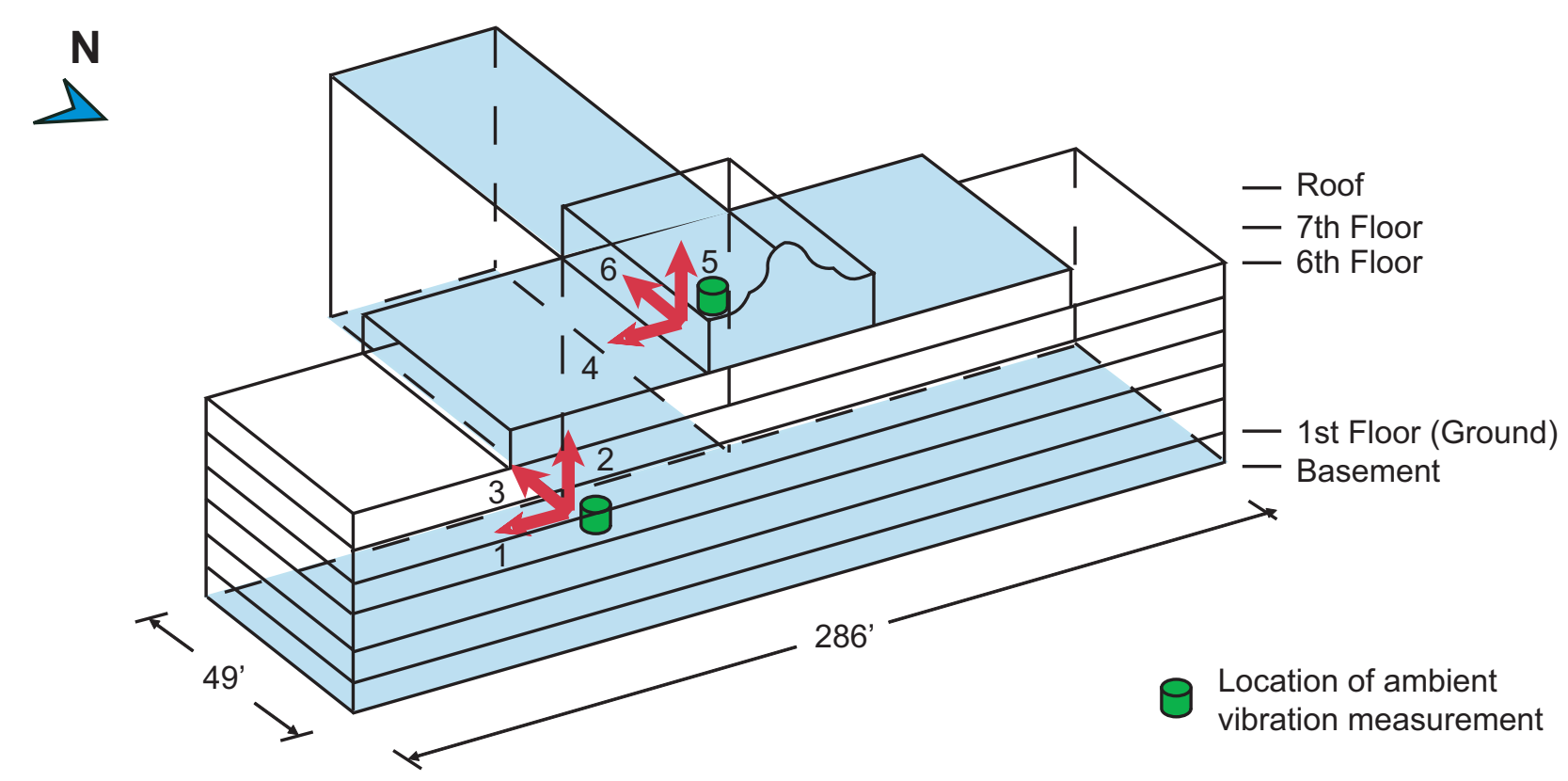

Figure 10. Instrumentation scheme and ambient vibration measurement locations for 4951 Arroyo Rd. 


\section{Station 1239 - Transamerica Pyramid}

\section{Montgomery Street, San Francisco}

The Transamerica Pyramid, shown in Figure 11, has been one of the tallest and most recognizable of San Francisco's buildings since its construction in 1972. The building has 48 stories above ground, plus a spire, which brings its total height to over 850 feet. Its lateral force-resisting system consists of steel moment frames which slowly step back to accommodate the sloped exterior walls. The building is extensively instrumented as shown in Figure 12, and its instruments recorded the 1989 Loma Prieta earthquake. The building's accelerometers are now connected to a real-time monitoring system which streams data to a limited number of clients via secure internet connection. Ambient vibration data was acquired using this real-time system; no ambient velocity data was taken.

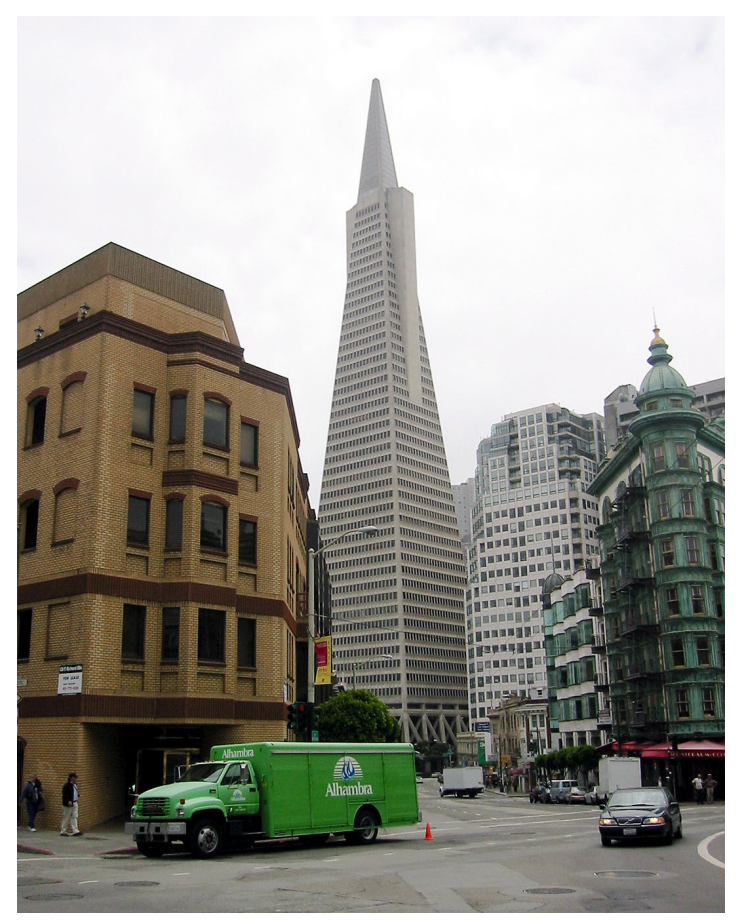

Figure 11. Exterior view of 600 Montgomery St. (photo by Dan Radulescu) 


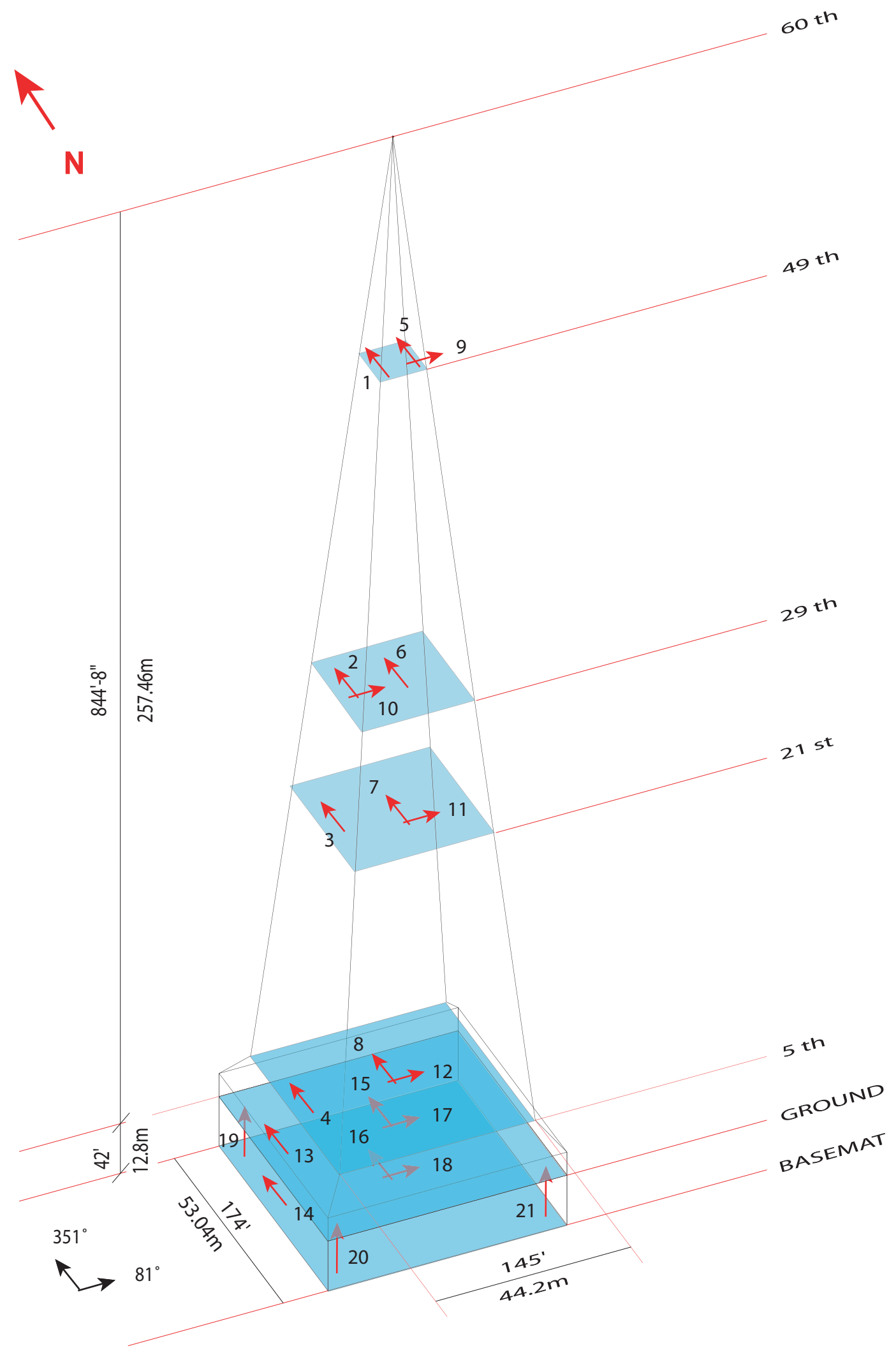

Figure 12. Instrumentation scheme for 600 Montgomery St. Lower floor channels are: 14, 15, 18, 19, 20,21 atop basemat, 13, 15, 17 at ground level, and 4, 8, 12 at $5^{\text {th }}$ floor. 


\section{Station 1662 - Pacific Park Plaza}

6363 Christie Avenue, Emeryville

The thirty-story Pacific Park Plaza building in Emeryville, shown in Figure 13, was constructed in 1984. The lateral force resisting system is a ductile concrete moment-resisting frame. The building has a delta wing plan (i.e. three wings equidistant at 120 degrees) and several re-entrant corners at the wing ends. There is a thin layer of young Bay Mud underlying the site. The building was extensively instrumented by the USGS with sensors configured as shown in Figure 14. The structural array is complemented by free-field and downhole instruments. The structural array and free-field instruments recorded the 1989 Loma Prieta earthquake on analog recorders, but all recorders at the site have since been replaced with digital ones.

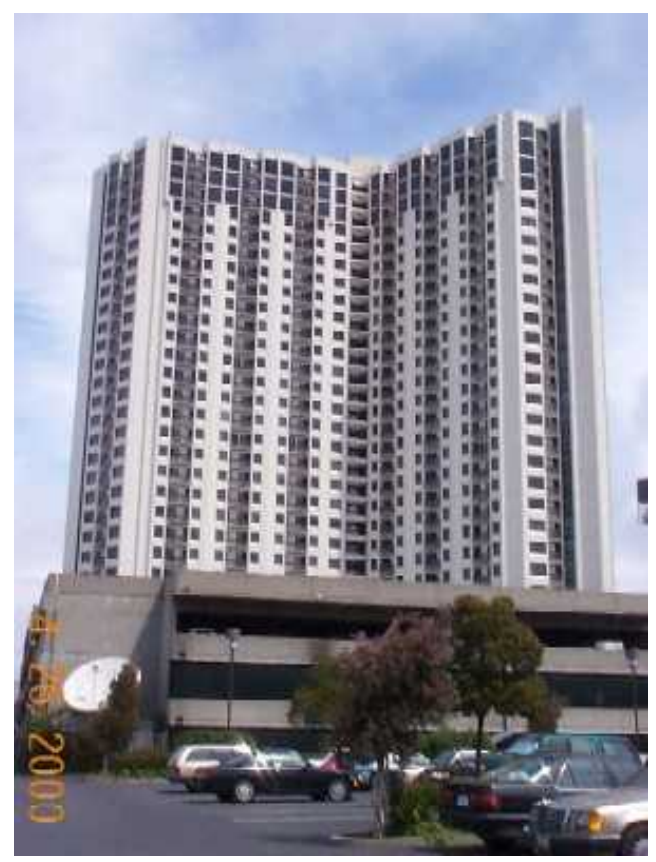

Figure 13. Exterior view of 6363 Christie Ave. with adjacent reinforced concrete parking garage in foreground (photo by Kent Fogleman). 


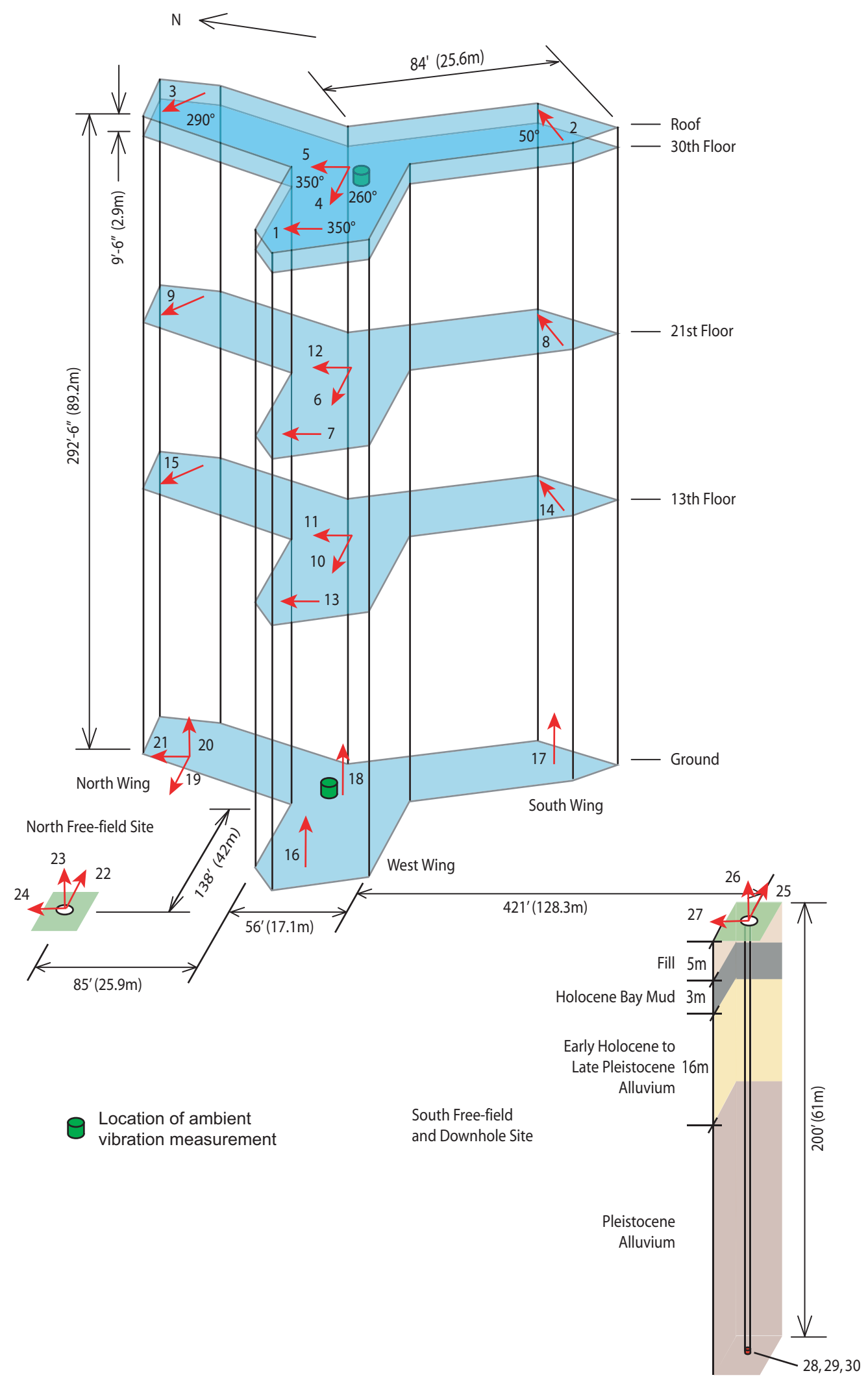

Figure 14. Instrumentation scheme and ambient vibration measurement locations for 6363 Christie Ave. Ambient velocity measurements taken on $30^{\text {th }}$ floor while permanent instruments are located on roof. 


\section{Station 5106 - Long Beach VA Hospital}

5901 East $7^{\text {th }}$ Street, Long Beach

The Long Beach VA Hospital, shown in Figure 15, is an 11-story non-ductile concrete structure constructed in the 1960s. The building was damaged in the M6.7 1994 Northridge earthquake and subsequently retrofitted with base isolation. The building's instrumentation scheme both before and after the retrofit are shown in Figure 16. The preretrofit scheme consisted of tri-axial analog instruments, which were replaced with a modern digital structural array following the retrofit. Several significant earthquakes were recorded prior to the retrofit, but no sizable earthquakes have been recorded since. Ambient vibration data was acquired using the permanent instrumentation system; no ambient velocity data was taken.

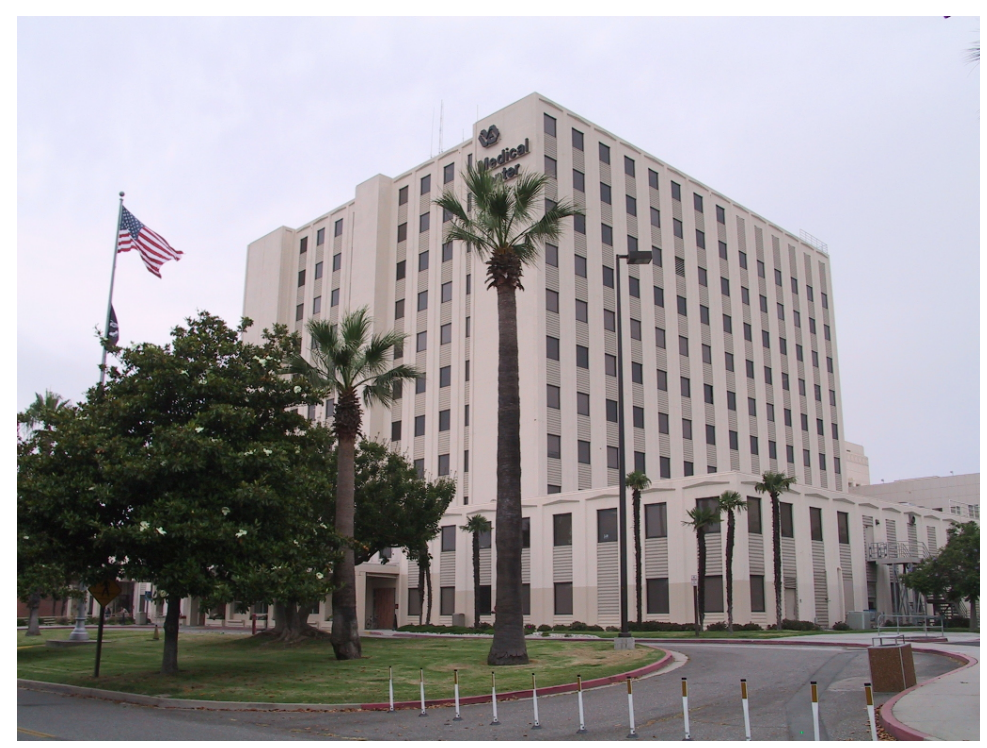

Figure 15. Exterior view of 5901 E. $7^{\text {th }}$ St. (photo by Arnold Acosta) 


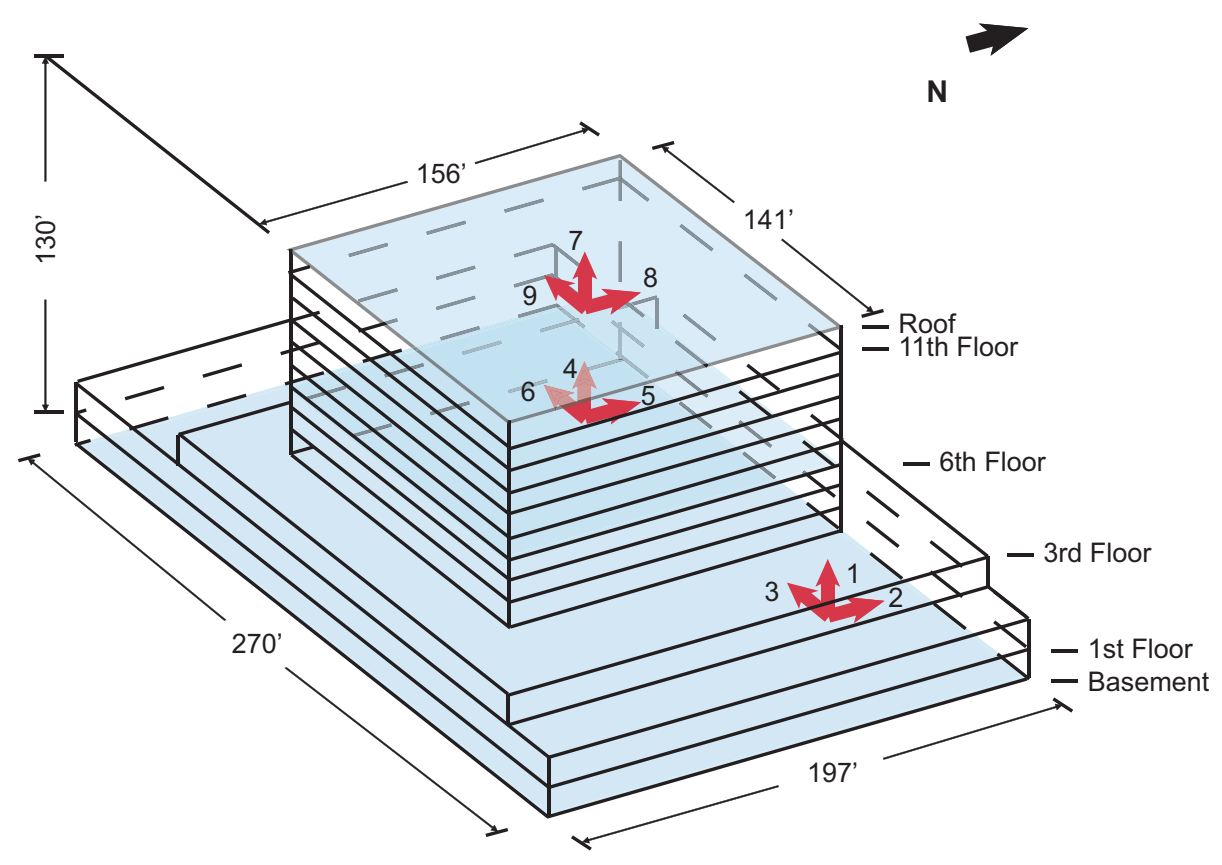

Before Retrofit

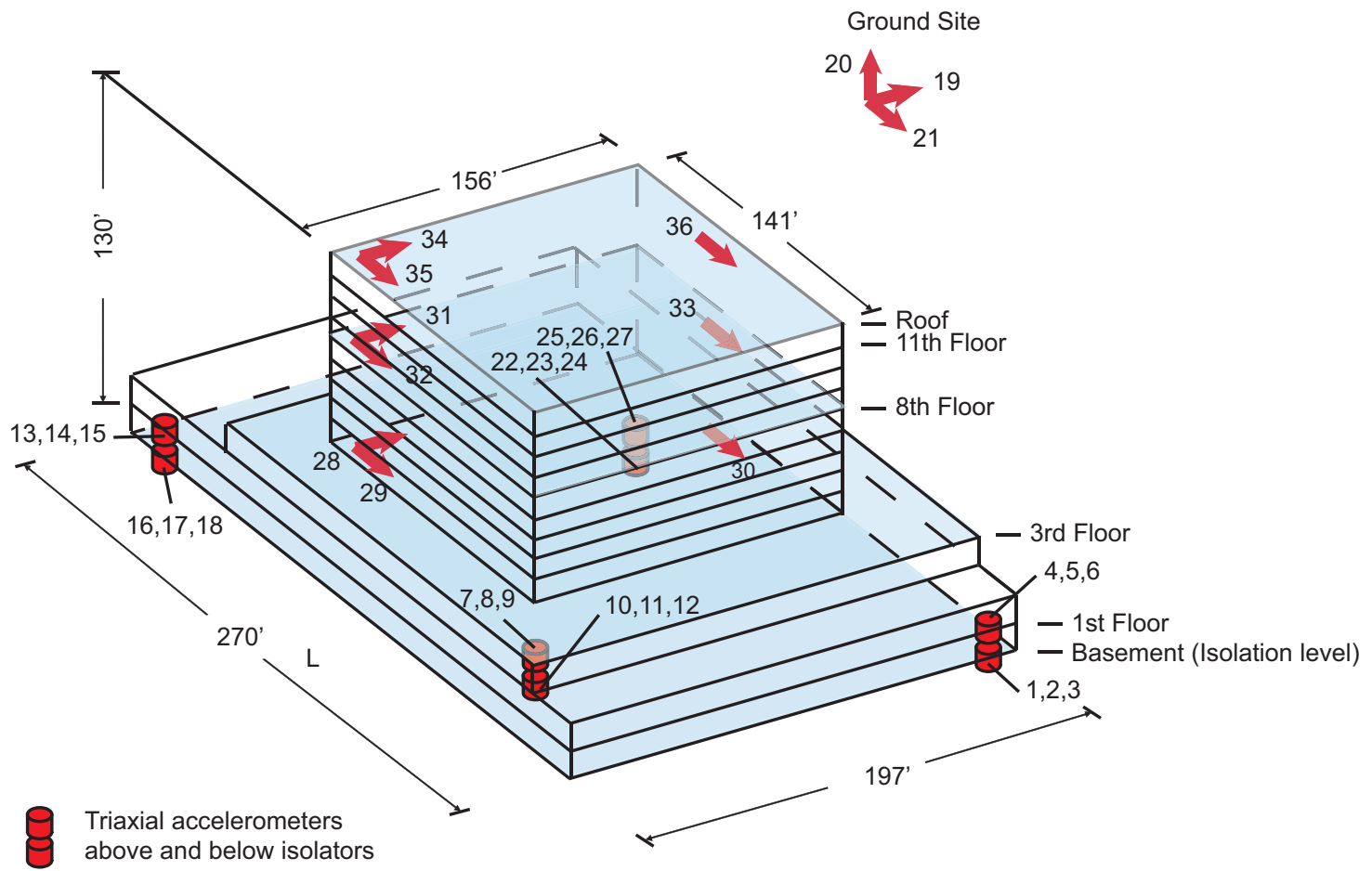

After Retrofit

Figure 16. Instrumentation scheme for $5901 \mathrm{E}$. $7^{\text {th }}$ St., showing configurations before (left) and after (right) seismic retrofit 


\section{Station 5229 - Loma Linda VA Hospital}

\section{Benton Street, Loma Linda}

The Loma Linda Veterans Administration hospital, shown in Figure 17, is a very large building which was constructed in the late 1970s. The structure has many reentrant corners, though no setbacks. The lateral forceresisting system consists of reinforced concrete shear walls. The building is situated in the vicinity of the San Jacinto fault zone. The building's current instrumentation configuration is shown in Figure 18. Currently, only the digital tri-axial instrument in the basement is being maintained, but this situation may improve soon. A number of earthquakes have been recorded by the analog structural array in the building, and a moderately sized strong-motion data set is available.
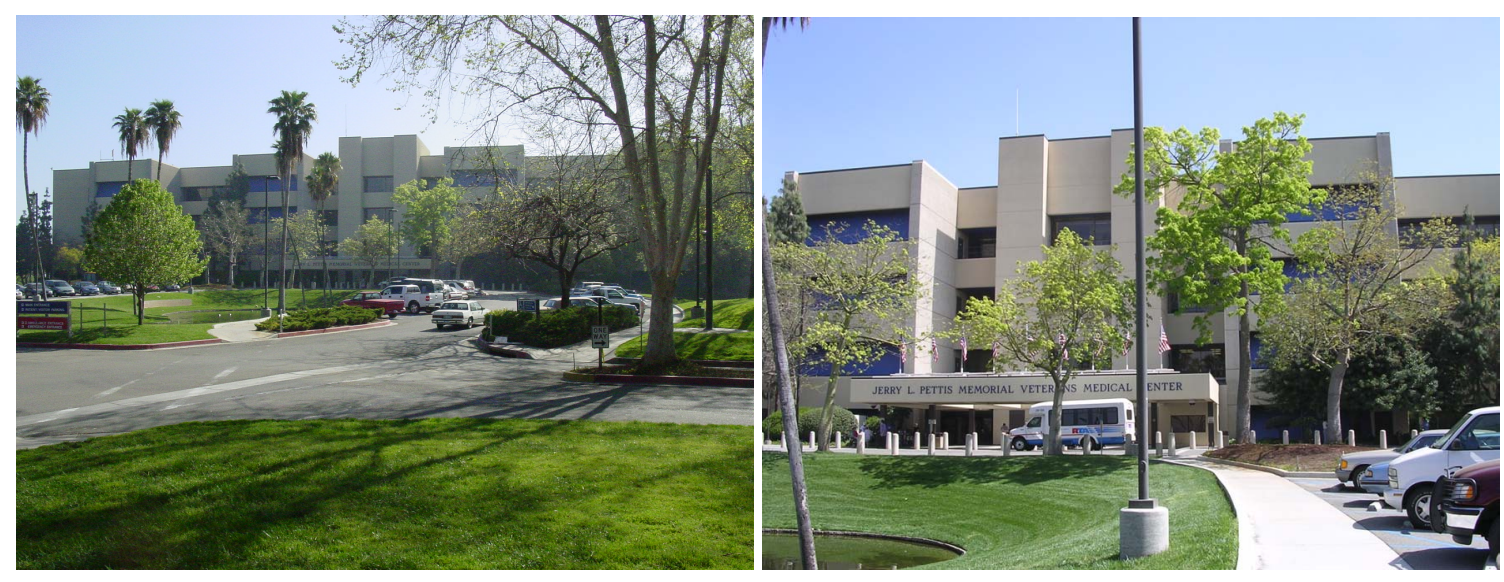

Figure 17. Wide-angle (left) and close-up (right) exterior views of 11201 Benton St. (photos by Janise Rodgers and François Dunand) 


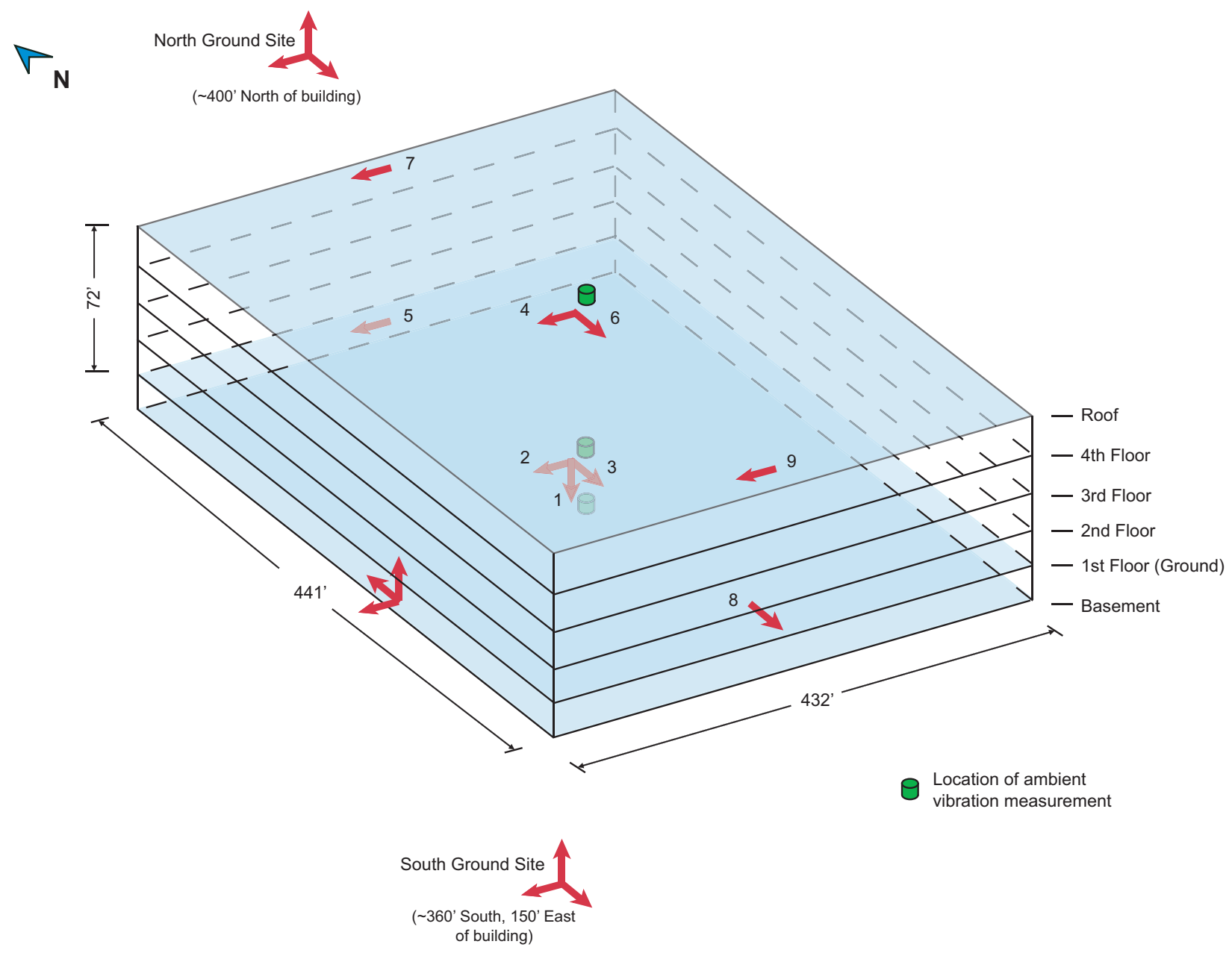

Figure 18. Instrumentation scheme and ambient vibration measurement locations for 11201 Benton St.

Accelerometer channel numbers are $1-3,5,8$ on the $1^{\text {st }}$ floor, and 4, 6, 7, 9 on the roof. A new digital tri-axial package is in the basement. Ambient vibration measurements were taken at the basement, $1^{\text {st }}$ floor and roof. 


\section{Station 5239 - Imperial Norwalk Centre}

\section{Imperial Highway, Norwalk}

The former Bechtel office building at 12440 Imperial Highway in Norwalk is now occupied by a number of local and federal law enforcement agencies. A current photograph of the building is not available. The building is a 7story steel moment-framed structure constructed in the early 1980's. The building has an unusually high aspect ratio (>3:1) in plan, but no significant vertical or plan irregularities. The building is extensively instrumented with sensors in the configuration shown in Figure 19. The analog structural array has recorded a number of Southern California earthquakes, including the 1987 Whittier Narrows and 1994 Northridge quakes.

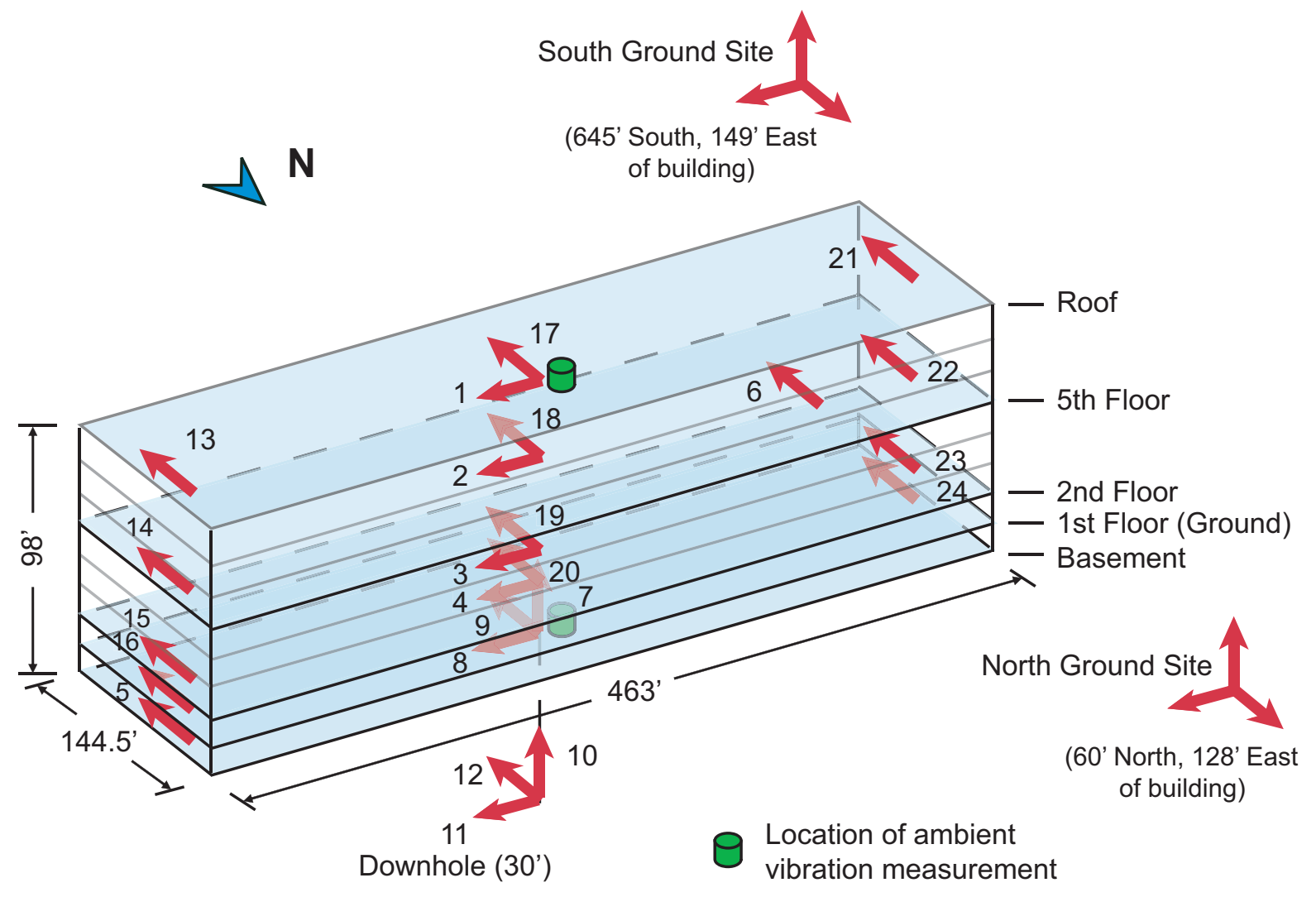

Figure 19. Instrumentation scheme and ambient vibration measurement locations for 12440 Imperial Hwy. Accelerometer channel numbers: 10-12 downhole; 5, 7-9 at basement; 4, 16, 20, 24 on $1^{\text {st }}$ floor; 3, 15, 19, 23 on $2^{\text {nd }}$ floor; $2,6,14,18,22$ on $6^{\text {th }}$ floor, 1, 13, 17, 18, 21 at roof. 


\section{Station 5245 - San Bernardino County Services Building}

\section{North Arrowhead Avenue, San Bernardino}

The five-story San Bernardino County Services Building was constructed in 1984. The building's structural system is a dual system with steel moment-resisting frames in the N-S direction and steel concentrically braced frames in the E-W direction. As shown in Figure 20, the building's geometry is basically L-shaped but very irregular, with numerous setbacks and re-entrant corners. Instrumentation consists of a 12-channel structural array and a separate tri-axial instrument in a basement mechanical room on the building's south side. Analog recorders were installed in 1987, and upgraded to digital recorders in 2002.
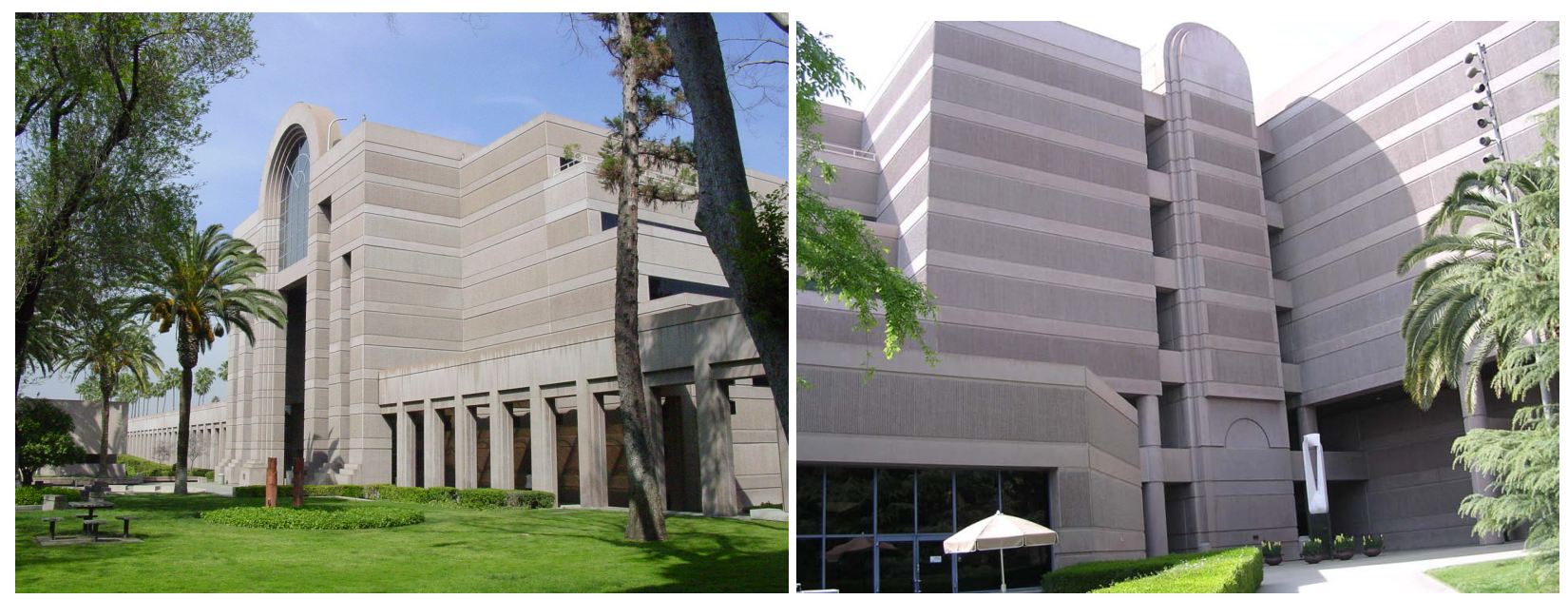

Figure 20. Front (left) and rear (right) exterior views of 345 N. Arrowhead Ave. (photos by Janise Rodgers and François Dunand) 


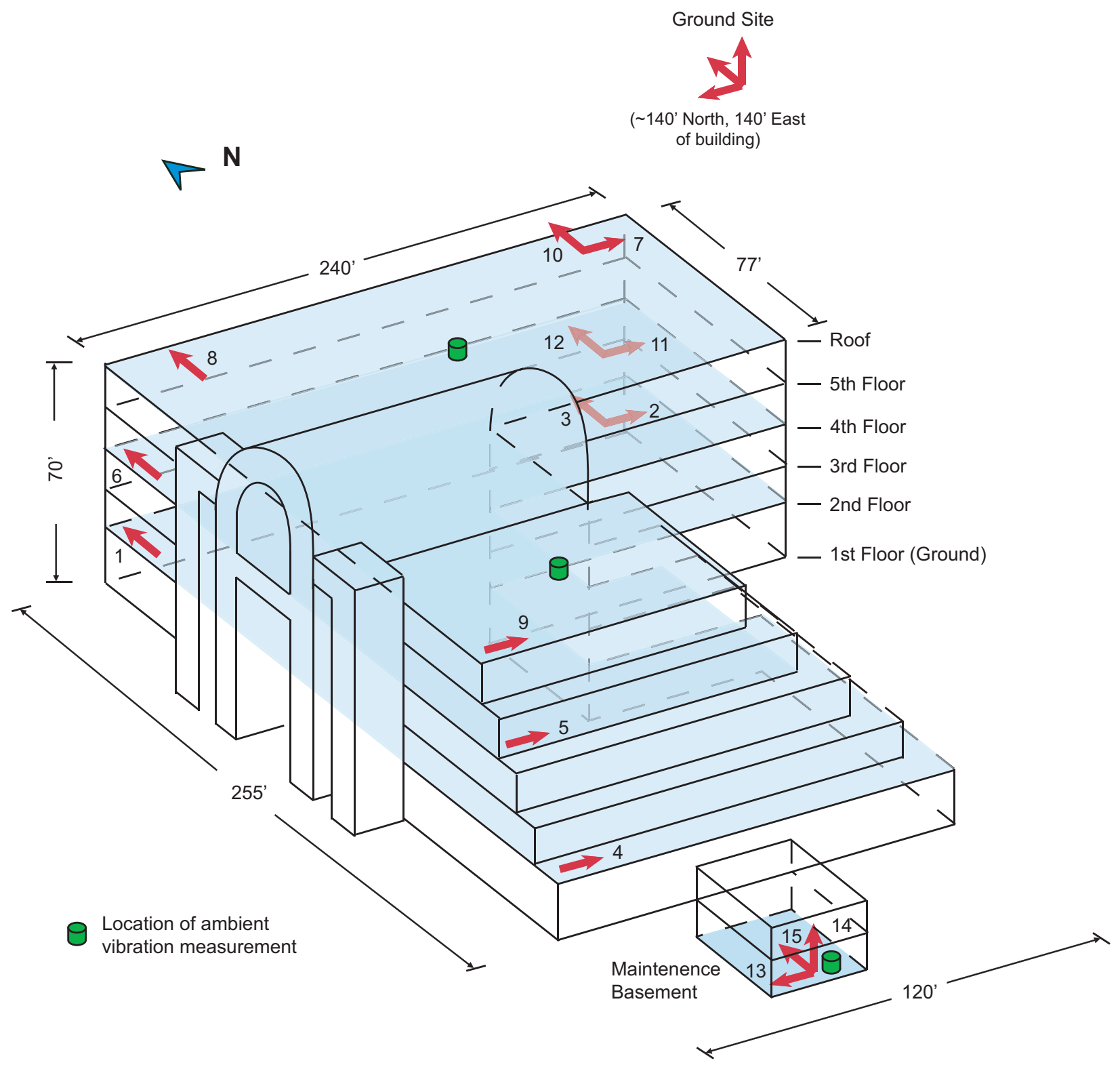

Figure 21. Instrumentation scheme and ambient vibration measurement locations for $345 \mathrm{~N}$. Arrowhead Ave. Ambient velocity measurements were taken at two locations on the roof and at one in the maintenance basement. 


\section{Station 5281- Brinderson Towers \#2}

19900 MacArthur Boulevard, Irvine

The 13-story Brinderson Towers are two nominally identical buildings which were constructed in the period from 1988 to 1992. The lateral force-resisting system of both buildings is a dual steel moment frame / eccentrically braced frame system. Both buildings have a notch in one corner at the base, as shown in Figure 22. The buildings are very regular otherwise. Tower 2 was instrumented with a 12-channel structural array in 1990 by the USGS. Several earthquakes, including the 1992 Landers and 1994 Northridge earthquakes, have been recorded by the structural array, and a small strong-motion data set is available.

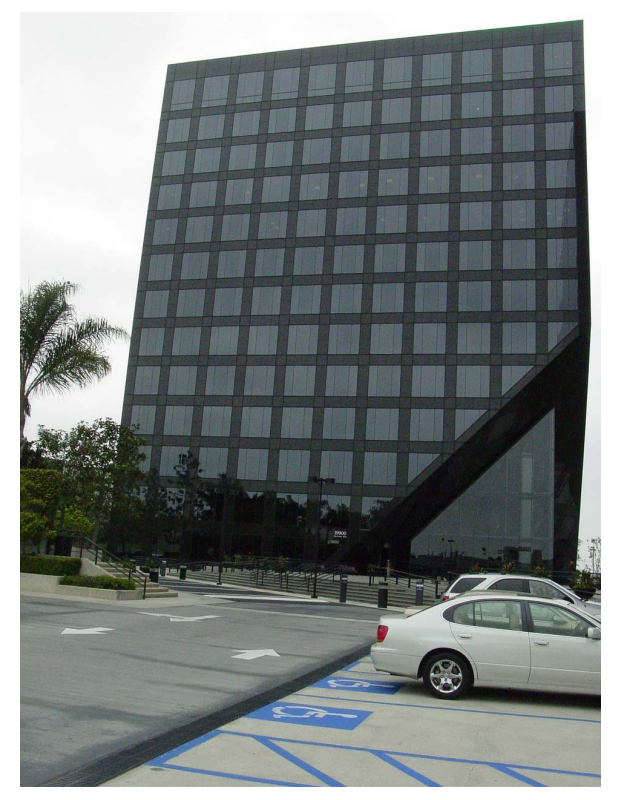

Figure 22. Exterior view of 19900 MacArthur Blvd., Tower 2 (photo by Janise Rodgers)

\section{N 1}

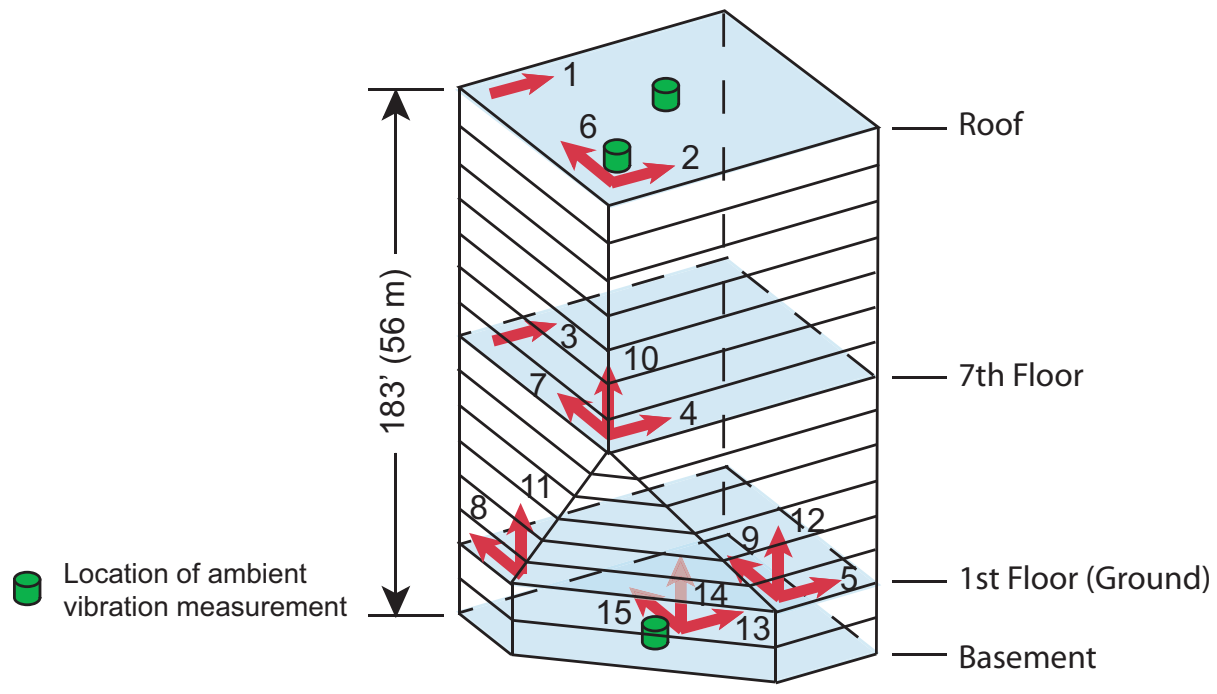

Figure 23. Instrumentation scheme and ambient vibration measurement locations for 19900 MacArthur Blvd. 


\section{Station 5407 - Millikan Library}

\section{California Institute of Technology campus, Pasadena}

Caltech's nine-story Millikan Library, shown in Figure 24, is one of the most extensively-studied buildings in the world. The building was constructed in 1966-67, and has recorded the building's response to a large number of earthquakes. An eccentric mass shaker is located on the roof, and numerous forced-vibration experiments have been conducted. The building's lateral force-resisting system consists of reinforced concrete shear walls in both directions. Early instrumentation consisted of tri-axial analog accelerometers at the basement and roof. The instrumentation was subsequently upgraded to the digital scheme shown in Figure 25, and there are now instruments on every floor, which are connected to both standard digital recorders and a web-based real-time monitoring system.

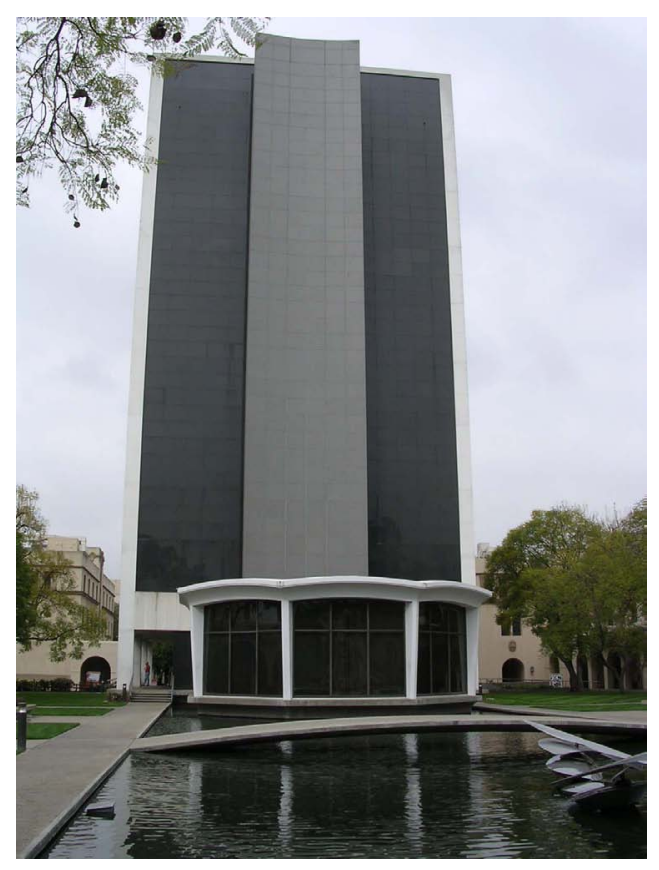

Figure 24. Exterior view of Millikan Library (photo by François Dunand)

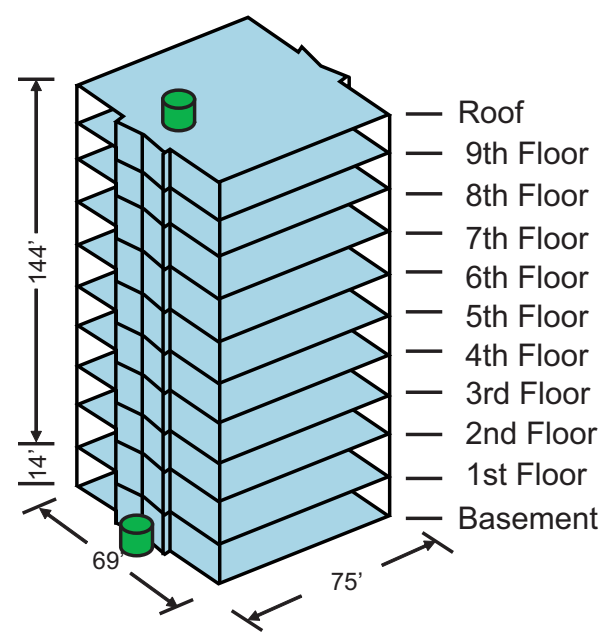

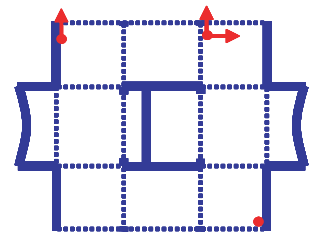

Basement
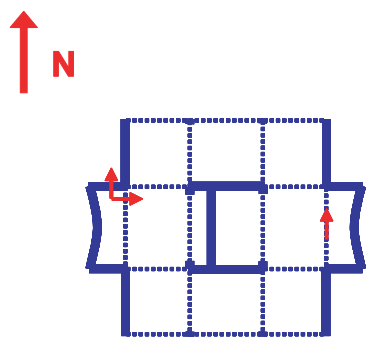

Floors 1-9 \& Roof
$\longrightarrow$ Horizontal Accelerometer
- Vertical Accelerometer
Location of ambient vibration measurement

Figure 25. Instrumentation scheme and ambient vibration measurement locations for Millikan Library 


\section{Ambient vibration testing}

\section{Equipment}

The ambient vibration tests carried out on each building were performed with vibration measurement equipment comprising two CityShark ${ }^{\mathrm{TM}^{*}}$ acquisition systems, each connected to one velocimeter (velocity transducer) as shown in Figure 26. The CityShark ${ }^{\mathrm{TM}^{*}}$ system was developed for specifically for ambient vibration measurements (Chatelain et al. 2000). The analog/digital conversion processor is 24-bit. The sampling frequency can be chosen from five values between 50 samples per second (sps) and 250 sps. The gain can be set between 1 and 16384 . The duration of recording can be set at any value between 1 and 60 minutes. This system is portable with its own battery and does not need a PC to run. The data are stored on a flashcard. The velocimeters are Lennartz LE-3D* with 3 components and a weight of $1.8 \mathrm{Kg}$. The natural (eigen) frequency is $1 \mathrm{~Hz}$ and the upper corner frequency is more than $80 \mathrm{~Hz}$.

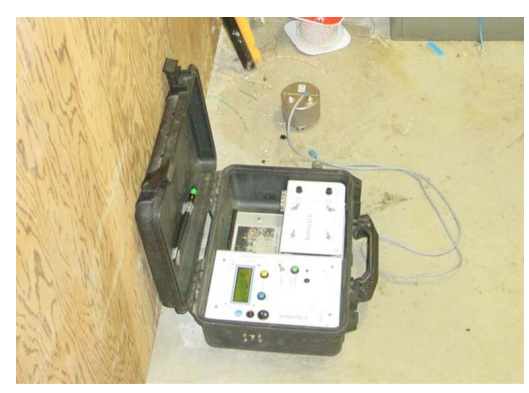

Figure 26. The CityShark ${ }^{*}$ recorder and the Lennartz LE-3D* velocimeter

\section{Procedure}

The following testing procedure was adopted was to obtain data suitable for computing the transfer function of the buildings. Ambient vibrations were recorded at the top and at the bottom of each tested building using the velocimeter test setup described in the previous section. These records were generally not taken simultaneously, but typically either overlapped or were taken consecutively. The velocimeters were located as close as possible to a permanent accelerometer. The records were 30 minutes long with a sampling frequency of $200 \mathrm{~Hz}$. The gain was adjusted to obtain the best amplified record on the horizontal component without clipping.

In the case of the Transamerica Pyramid and the Long Beach VA Hospital, on-site ambient vibration testing using velocimeters was not performed due to logistical constraints. Ambient data for these buildings were obtained from accelerometers in the permanent structural arrays, and were obtained simultaneously at all channels. In addition, ambient vibrations were recorded on both velocimeters and permanent accelerometers for comparison purposes at three buildings with different structural systems.

\footnotetext{
* Use of trade, firm, or product names does not imply endorsement by the U.S. Government or the authors.
} 


\section{Data}

The locations and orientations of the velocimeters are summarized in Table 2. The indicated orientation is the local north azimuth for the velocimeter. The last column shows whether or not ambient vibrations were recorded using the permanent accelerometers in the structural array. Data listed in the table are available from the USGS National Strong Motion Program (NSMP) website (http://nsmp.wr.usgs.gov).

The CityShark ${ }^{*}$ files are made of a header with record information, followed by three columns corresponding to the vertical, local north and local east components of the ambient motion. The units of theses columns are counts and the conversion procedure is:

To obtain Volts : multiply by $2500000.0 / 32767.0$ and divide by the Gain (see header)

To obtain $10^{-6} \mathrm{~m} / \mathrm{s}$ : divide the volts by 400.0 for the velocimeter Lennartz LE-3D*

Table 2. Location of ambient vibration records

\begin{tabular}{|c|c|c|c|c|c|c|c|}
\hline $\begin{array}{l}\text { NSMP } \\
\text { Station }\end{array}$ & Building Name & Story & Location & $\begin{array}{l}\text { Sensor } N \\
\text { Azm (deg) }\end{array}$ & $\begin{array}{l}\text { Near } \\
\text { Instrumt. }\end{array}$ & $\begin{array}{l}\text { CityShark } \\
\text { Filename }\end{array}$ & $\begin{array}{l}\text { Ambient } \\
\text { Acc Data }\end{array}$ \\
\hline \multirow[t]{2}{*}{482} & \multirow{2}{*}{$\begin{array}{l}\text { LA County Public } \\
\text { Works Headquarters }\end{array}$} & 12th & Center & 0 & 0699-1 & 03240053.001 & No \\
\hline & & Basement & Center & 0 & 0699-10 & 03240035.004 & No \\
\hline \multirow[t]{2}{*}{804} & \multirow{2}{*}{$\begin{array}{l}\text { Whittier Lutheran } \\
\text { Towers }\end{array}$} & Roof & Center & 0 & 1071 & 03232301.003 & No \\
\hline & & Basement & Center & 0 & 1069 & 03232300.004 & No \\
\hline \multirow[t]{2}{*}{1103} & \multirow[t]{2}{*}{ Great Western Savings } & Roof & W. core & 351 & 0293-6 & 03252057.004 & No \\
\hline & & Basement & W. core & 351 & 0144 & 03252021.003 & No \\
\hline \multirow[t]{2}{*}{1225} & \multirow{2}{*}{$\begin{array}{l}\text { San Francisco VA } \\
\text { Hospital }\end{array}$} & 7th & Center & 5 & 0767 & 03261835.002 & No \\
\hline & & Basement & Center & 5 & 0604 & 03261749.001 & No \\
\hline \multirow[t]{2}{*}{1226} & \multirow[t]{2}{*}{ Livermore VA Hospital } & 7th & Center & 305 & 0854 & 03251831.002 & No \\
\hline & & Basement & Center & 305 & 0602 & 03251740.001 & No \\
\hline 1239 & Transamerica Pyramid & & & & & & Yes \\
\hline \multirow[t]{2}{*}{1662} & \multirow[t]{2}{*}{ Pacific Park Plaza } & 30th & Cent. core & 350 & $2141-1$ & 03252335.006 & Yes \\
\hline & & Ground & Cent. core & 350 & $0615-6$ & 03252241.005 & Yes \\
\hline 5106 & $\begin{array}{l}\text { Long Beach VA } \\
\text { Hospital }\end{array}$ & & & & & & Yes \\
\hline \multirow[t]{3}{*}{5229} & \multirow[t]{3}{*}{$\begin{array}{l}\text { Loma Linda VA } \\
\text { Hospital }\end{array}$} & Roof & Center & 0 & $0230-4$ & $\begin{array}{l}03221849.001 \\
03221953.002\end{array}$ & No \\
\hline & & Ground & Center & 0 & $0230-1$ & 03221851.001 & No \\
\hline & & Basement & Center & 0 & none & 03221940.002 & No \\
\hline \multirow[t]{2}{*}{5239} & \multirow[t]{2}{*}{ Imperial Norwalk Centre } & Roof & Center & 0 & $0128-5$ & 03232051.002 & No \\
\hline & & Basement & Center & 0 & $0127-7$ & 03232046.003 & No \\
\hline \multirow[t]{3}{*}{5245} & \multirow{3}{*}{$\begin{array}{l}\text { San Bernardino County } \\
\text { Services Building }\end{array}$} & Roof & North side & 0 & $1578-8$ & 03222146.003 & No \\
\hline & & & South side & 0 & $1578-9$ & 03222220.004 & No \\
\hline & & Basement & South side & 0 & 1462 & 03222130.001 & No \\
\hline \multirow[t]{3}{*}{5281} & \multirow[t]{3}{*}{ Brinderson Towers \#2 } & Roof & S. corner & 330 & $1034-2$ & 03231804.001 & Yes \\
\hline & & & Center & 330 & none & 03231841.002 & No \\
\hline & & Basement & & 330 & & 03231813.001 & Yes \\
\hline \multirow[t]{2}{*}{5407} & \multirow[t]{2}{*}{ Millikan Library } & Roof & West end & 0 & 0133-16 & 03241844.001 & Yes \\
\hline & & Basement & West end & 0 & $0134-4$ & 03241854.001 & Yes \\
\hline
\end{tabular}

\footnotetext{
${ }^{*}$ Use of trade, firm, or product names does not imply endorsement by the U.S. Government or the authors.
} 


\section{Earthquake strong-motion data}

Recorded strong-motion data available at the time of publication are listed by building in Table 3. Data currently being processed, which will be available soon, are listed in Table 4. Depending on the age and source of the data, processing procedures vary somewhat, and are noted in table footnotes. Magnitudes are moment magnitude unless otherwise noted and were obtained from the Southern California Earthquake Data Center (SCEDC) or the Northern California Earthquake Data Center (NCEDC). Most data recorded prior to the late 1990s were recorded on analog instruments and subsequently digitized. Comments regarding digitizing (such as the existence of stalls in some original analog recordings) are located in the data file headers for each event. Digital data are available from the USGS National Strong Motion Program (NSMP) website (http://nsmp.wr.usgs.gov).

Table 3. Strong-motion data available for study buildings

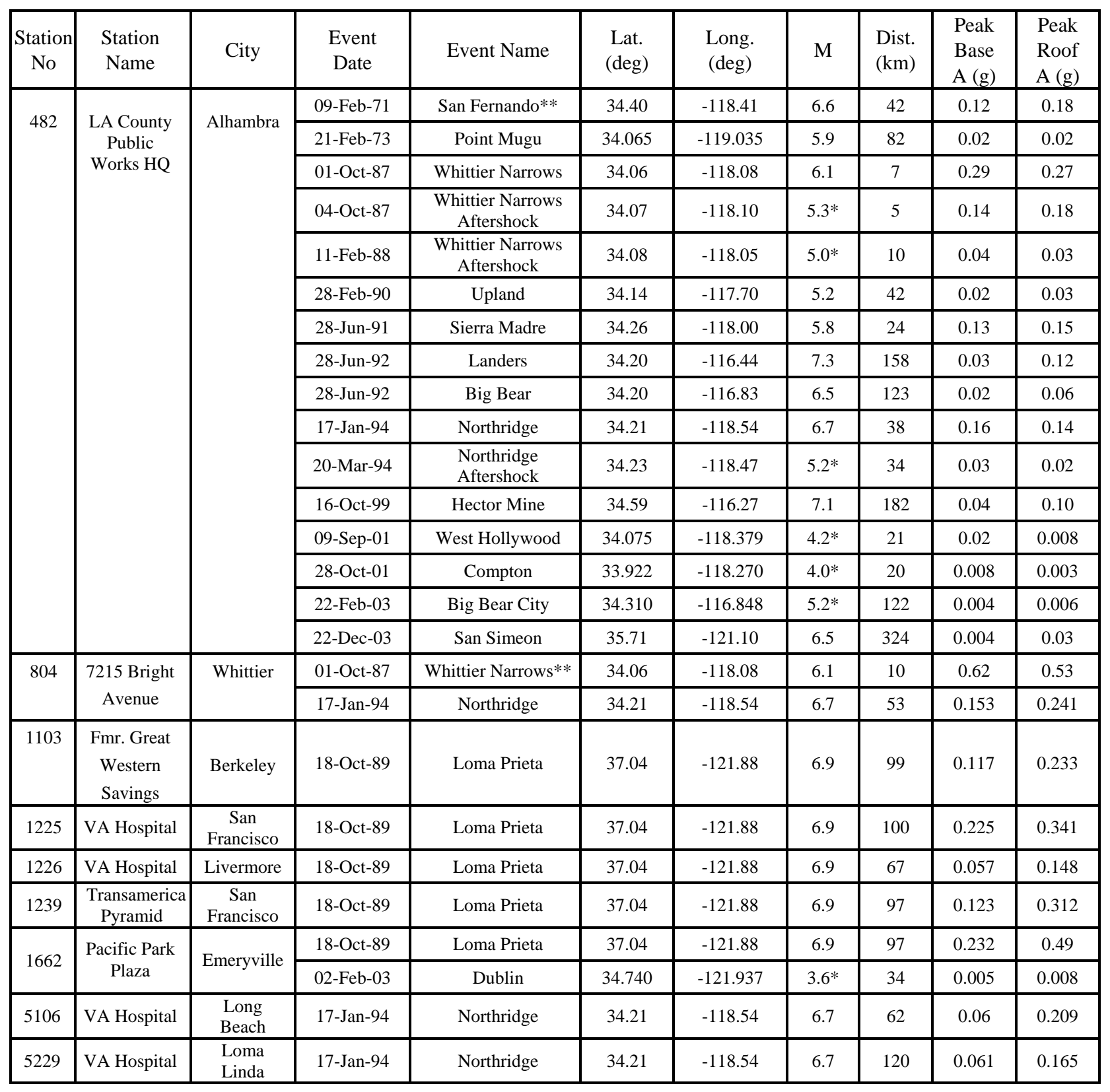




\begin{tabular}{|c|c|c|c|c|c|c|c|c|c|c|}
\hline $\begin{array}{c}\text { Station } \\
\text { No }\end{array}$ & $\begin{array}{l}\text { Station } \\
\text { Name }\end{array}$ & City & $\begin{array}{l}\text { Event } \\
\text { Date }\end{array}$ & Event Name & $\begin{array}{l}\text { Lat. } \\
\text { (deg) }\end{array}$ & $\begin{array}{l}\text { Long. } \\
\text { (deg) }\end{array}$ & M & $\begin{array}{l}\text { Dist. } \\
(\mathrm{km})\end{array}$ & $\begin{array}{l}\text { Peak } \\
\text { Base } \\
\text { A (g) }\end{array}$ & $\begin{array}{l}\text { Peak } \\
\text { Roof } \\
\text { A (g) }\end{array}$ \\
\hline 5239 & $\begin{array}{c}12440 \\
\text { Imperial } \\
\text { Hwy }\end{array}$ & Norwalk & 17-Jan-94 & Northridge & 34.21 & -118.54 & 6.7 & 55 & 0.061 & 0.148 \\
\hline \multirow{2}{*}{5245} & \multirow{2}{*}{$\begin{array}{l}\text { County } \\
\text { Services } \\
\text { Building }\end{array}$} & \multirow{2}{*}{$\begin{array}{c}\text { San } \\
\text { Bernardino }\end{array}$} & 28-Jun-92 & Landers & 34.20 & -116.44 & 7.3 & 79 & 0.09 & 0.36 \\
\hline & & & 17-Jan-94 & Northridge & 34.21 & -118.54 & 6.7 & 116 & 0.045 & 0.243 \\
\hline 5281 & $\begin{array}{l}\text { Brinderson } \\
\text { Towers \#2 } \\
\end{array}$ & Irvine & 17-Jan-94 & Northridge & 34.21 & -118.54 & 6.7 & 88 & 0.063 & 0.188 \\
\hline \multirow{5}{*}{5407} & \multirow{5}{*}{$\begin{array}{c}\text { Millikan } \\
\text { Library }\end{array}$} & \multirow{5}{*}{ Pasadena } & 12-Sep-70 & Lytle Creek** & 34.27 & -117.54 & $5.2 *$ & 56 & 0.019 & 0.055 \\
\hline & & & 09-Feb-71 & San Fernando** & 34.40 & -118.41 & 6.6 & 39 & 0.20 & 0.35 \\
\hline & & & 03-Sep-02 & Yorba Linda & 33.917 & -117.776 & $4.8^{*}$ & 40 & 0.006 & 0.009 \\
\hline & & & 22-Feb-03 & Big Bear City & 34.310 & -116.848 & $5.2^{*}$ & 119 & $\mathrm{n} / \mathrm{a}$ & 0.008 \\
\hline & & & 22-Dec-03 & San Simeon & 35.71 & -121.10 & 6.5 & 323 & 0.002 & 0.008 \\
\hline
\end{tabular}

* Local magnitude - all other values moment magnitude

** Processed with Caltech "Blue book" procedures (Hudson et al. 1971). Standard USGS procedures (Stephens and Boore 2004) used otherwise.

Table 4. Data currently being processed

\begin{tabular}{|c|c|c|c|c|c|c|c|c|}
\hline $\begin{array}{c}\text { Station } \\
\text { No }\end{array}$ & Station Name & City & $\begin{array}{l}\text { Event } \\
\text { Date }\end{array}$ & Event Name & $\begin{array}{l}\text { Lat. } \\
\text { (deg) }\end{array}$ & $\begin{array}{l}\text { Long. } \\
\text { (deg) }\end{array}$ & M & $\begin{array}{l}\text { Dist. } \\
\text { (km) }\end{array}$ \\
\hline \multirow{2}{*}{5106} & \multirow{2}{*}{ VA Hospital } & \multirow{2}{*}{ Long Beach } & 01-Oct-87 & Whittier Narrows & 34.06 & -118.08 & 5.9 & 32 \\
\hline & & & 04-Oct-87 & Whittier Narrows Aftershock & 34.07 & -118.10 & $5.3^{*}$ & 33 \\
\hline \multirow{2}{*}{5229} & \multirow{2}{*}{ VA Hospital } & \multirow{2}{*}{ Loma Linda } & 28-Jun-92 & Landers & 34.20 & -116.44 & 7.3 & 76 \\
\hline & & & 28-Jun-92 & Big Bear & 34.20 & -116.83 & 6.5 & 42 \\
\hline 5239 & 12440 Imperial Hwy & Norwalk & 01-Oct-87 & Whittier Narrows & 34.06 & -118.08 & 6.1 & 16 \\
\hline \multirow{2}{*}{5281} & \multirow{2}{*}{ Brinderson Towers \#2 } & \multirow{2}{*}{ Irvine } & 28-Jun-92 & Landers & 34.20 & -116.44 & 7.3 & 144 \\
\hline & & & 28-Jun-92 & Big Bear & 34.20 & -116.83 & 6.5 & 113 \\
\hline
\end{tabular}

\section{Acknowledgments}

The authors gratefully acknowledge the assistance of the following persons in assembling these datasets: Chris Stephens, Kent Fogleman, and Roy Tam of the USGS National Strong Motion Program Data Center, and the building managers and operations personnel at each building tested. Reviewers John Evans and Kent Fogleman provided numerous helpful suggestions.

\section{References}

Çelebi, M (1993). Dynamic characteristics of five tall buildings during strong and low-amplitude motions, The structural design of tall buildings, Vol. 2, 1-15.

Çelebi, M. (1998). Performance of building structures - a summary. In U.S. Geological Survey Professional Paper 1552-C, Menlo Park, California, C5-C76.

Chatelain, J. L., P. Guéguen, B. Guillier, J. Fréchet, F. Bondoux, J. Serrault, P. Sulpice and J.M. Neuville (2000). CityShark : A user-friendly instrument dedicated to ambient noise (microtremor) recording for site and building response studies, Seismological Research Letters, Vol. 71(6), 698-703. 
Hudson, D. E., A. G. Brady, M. D. Trifunac, and A. Vijayaraghavan (1971). Strong motion accelerograms, Digitized and plotted data, Part A, Report No. EERL 71-50, Earthquake Engineering Research Library, California Institute of Technology, Pasadena, Preface to the series.

Mar, D., L. Panian, R.A. Dameron, B.E. Hansen, S. Vahdani, D. Mitchell, and J. Peterson (2000). Performance-based seismic upgrade of a 14-story suspended slab building using state-of-the-art analysis and construction techniques, Proceedings, Structural Engineers Association of California 2000 Convention, Vancouver, British Columbia.

Stephens, C.D. and D.M. Boore (2004). ANSS/NSMP strong-motion record processing and procedures, Proceedings, COSMOS Invited Workshop on Record Processing Guidelines, Consortium of Organizations for Strong Motion Observation Systems, Richmond, California. 